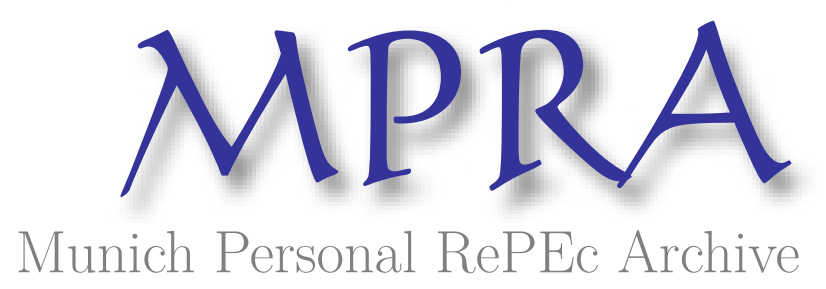

Schooling, employer learning, and internal labor market effect: Wage dynamics and human capital investment in the Japanese steel industry, 1930-1960s

Nakabayashi, Masaki

Institute of Social Science, The University of Tokyo

29 April 2011

Online at https://mpra.ub.uni-muenchen.de/30597/

MPRA Paper No. 30597, posted 03 May 2011 17:03 UTC 


\title{
Schooling, employer learning, and internal labor market effect Wage dynamics and human capital investment

\author{
in the Japanese steel industry, 1930-1960s*
}

\author{
ISS Discussion Paper Series \\ F-153 \\ April 2011 \\ Masaki Nakabayashi ${ }^{\dagger}$ \\ Institute of Social Science \\ The University of Tokyo
}

\begin{abstract}
Employer learning model predicts the impact of schooling, an observable signal, on wages decreases with accumulation of experience. Workers, however, have incentives to invest in general human capital both at schools and workplaces such that experience and schooling are complements unless the current employer commits to long-term employment. Microanalysis of Japanese steel industry indeed shows that experience before employed by the firm is complementary to schooling and the complementarity effect dominates employer learning effect while wage growth after employed is consistent with learning hypothesis. It suggests that previous evidences of employer learning might contain internal labor market effect.
\end{abstract}

Key words: employer learning, schooling and wages, internal labor market effect.

JEL: J31, N35, J24.

*This research has been financially supported by the JSPS Grant-in-Aid (22243022) and the Mitsubishi Foundation.

${ }^{\dagger}$ The author is thankful to support from the Kamaishi Iron Works, Nippon Steel Company. He also appreciates helpful comments from Daiji Kawaguchi, Soohyung Lee, Yuji Genda, Hideo Owan, Ryuichi Tanaka, Konosuke Odaka, Takashi Kurosaki, Norihito Abe, Chiaki Moriguchi, Rasmus Lentz, Peter Howlett, Janet Hunter, Keisuke Nakamura, Naofumi Nakamura, Michio Nitta, Junichiro Ishida, Keiko Yoshida, and the participants of seminars and meetings at the University of Tokyo, London School of Economics and Political Science, Free University of Berlin, University of Tübingen, Kwansei Gakuin University, and Hitotsubashi University. Corresponding address: Institute of Social Science, The University of Tokyo, Hongo 7-3-1, 103-0033 Tokyo, Japan. e-mail: mn@iss.u-tokyo.ac.jp 


\section{Introduction}

\subsection{Total experience or tenure?: Employers' learning and employees' incentives of human capital investment}

While human capital or productivity of individual workers are hard to observe, educational background is one of the observable proxies supposed to be correlated to skill and future performance. It entices employers to statistically discriminate employees based on educational background, and the statistical discrimination could lead to considerable gap between wages and realized performance. ${ }^{1}$ Wage could grow either because human capital is invested in after employed or because the employer learns employees' ability endowed before employed, and it is generally difficult to empirically distinguish them. ${ }^{2}$ Inspired by the screening hypothesis, rich empirical results supporting "sheepskin effects" of schooling have been presented for the US and other several economies. ${ }^{3}$ While there are evidences that schooling could enhance productivity, not only work just as a signal, and the quality of education, not only diploma, does matter, ${ }^{4}$ it does not necessarily contradict with screening hypothesis. Schooling works as a strong signal as well as increases productivity. It is established that "sheepskin effects" themselves exist in all of developed, developing, and even planed economies. Then the issue in the literature has come to how the effects differ due to institutional arrangements, such as possible discrimination of gender, ethnic, or racial minority, ownership structure of firm, or regime of state.

Employer learning is one of the most exciting focal points of such a comparative analysis. The founders of screening models had interests both in education as a screening device itself and in social benefit of screening device to improve matching in the job market. Focusing on the former and considering rich empirical results to support it, the learning models established by Farber and Gibbons (1996) and Altonji and Pierret (2001) provide a clear prediction under

\footnotetext{
${ }^{1}$ While the founders of "education as screening" hypothesis as assumed education just as a screening device, it could be extended such that education also enhances productivity. Spence (1973), pp. 358-368. Arrow (1973), pp. 284-287. Tabman and Wales (1973), pp. 43-49. Stiglitz (1975), pp. 175-178. Spence (2002), pp. $436-443$.

${ }^{2}$ Stigler (1962), pp. 100-101.

${ }^{3}$ For the US, Riley (1979), pp.s240-s251, Lang and Kropp (1987), pp. 618-623, Hungerford and Solon (1987), pp. 175-177, Belman and Heywood (1991), pp. 721-723, Heywood (1994), pp. 228-232, Jaeger and Page (1996), pp. 734-738, Belman and Heywood (1997), pp. 628-635, Park (1999), pp. 238-240,Tyler, Murnane and Willett (2000), pp. 445-447, Bedard (2001), pp. 760-774, Pinkston (2003), pp. 651-656, Bollinger and Hirsch (2006), pp. 511-513, Trostel and Walker (2004), pp. 1965-1966, Clark and Jaeger (2006), pp. $772-788$. Bitzan (2009), pp. 761-764. Hansen, Weisbrod and Scanlon (1970), pp. 411-416, also gives some evidences that became a part of screening hypothesis. For Japan, Bauer, Dross and Haisken-DeNew (2005), pp. 323-331. For the UK, MacGuinnes (2003), pp. 599-606, Silles (2008), pp. 218-219. For Canada, Ferrer and Riddell (2008), pp. 885-902, Ferrer and Riddell (2002), pp. 191-211, Caponi and Plesca (2009), pp. 1113-1124. For Spain, Pons and Blanco (2005), pp. 336-343, Pons (2006), pp. 144-151. For Czech, a transition economy, Münich, Svejnar and Terrell (2005a), pp. 104-119, and Münich, Svejnar and Terrell (2005b), pp. 280-293, which examine differences over regimes, firm ownerships, and gender during the transition period. Denny and Harmon (2001), p. 636, gives a quick comparison among the US, the UK, Canada, Ireland, and Sweden.

${ }^{4}$ Those evidences include Layard and Psacharopoulos (1974), pp. 989-992, Wolpin (1977), pp. 954-957. Groot and Oosterbeek (1994), pp. 319-321, Card and Krueger (1992), pp. 31-36, for the US, Chevalier, Harmon, Walker and Zhu (2004), pp. F505-516, for the UK, and Patrinos (1996), pp. 171-173, for Guatemala.
} 
the competitive labor market that impact of schooling on wage decreases over workers' experience in the labor market as employers learn workers' types hidden at the time when they join the labor market. This learning effect is in estimation practice captured by non-increasing coefficient of the interaction of schooling and experience on a wage regression, and their empirical results support the prediction quite well, followed by supporting works about the US labor market. ${ }^{5}$

A simple, but not negligible feature common with Farber and Gibbons (1996) and Altonji and Pierret (2001) is in that they do not differentiate workers' experience before and after entering long-term employment, hence implicitly assume that learning go through "public"ly, or, symmetrically between incumbent employer and outside employers and that interaction between schooling and experience in principle do not change even after workers are successfully employed by a large firm that commits to long-term employment.

The employer learning hypothesis is straightforward from the viewpoint of employers who use educational background as a screening device and consistent empirical evidence has been presented as well. There still exists, however, some point yet to be inquired. Non-increasing coefficient of interaction term between schooling and experience implies not only that the employer is learning but also that schooling and experience are not complements, or their complementarity effect was sufficiently weak to be dominated by the employer's learning effect. ${ }^{6}$ If non-increasing coefficient of interaction between schooling and experience observed, the result itself is a puzzle from the viewpoint of employees' incentives for human capital investment, observed under technology-skill complementarity.

In the German case, for instance, as Gathmann and Schoenberg (2010) clearly demonstrates, young workers typically invest in "potable" general human capital as switching jobs several times in their early stages of career, and then enter employment of long-term basis. ${ }^{7}$ Also, productivity of labor and education of worker are thought to be closely correlated since the early 20th century, as industrial economies have experienced technology-skill/education complementary development. ${ }^{8}$ In fact, educational background of workers has accordingly emerged as the important proxy of ability in workplaces exactly on this context of technologyskill/education complementarity.

Under the technology-skill/education complementary development, workers likely choose work experiences to invest in general human capital complementary to their educational background before he/she joins a firm that commits to long-term employment and internal promotion, i.e., internal labor market policy. Then schooling and experience might be complements. This effect would work to make interaction between schooling and work experience increasing over time.

On the other hand, if the current employee commits to long-term employment and internal promotion, then the employee has incentives of investment in the industry-specific and/or firmspecific human capital, ${ }^{9}$ which might be less complementary to schooling, an opportunity of

\footnotetext{
${ }^{5}$ Farber and Gibbons (1996), pp. 1010-1018. Altonji and Pierret (2001), pp. 316-323. Lange (2007), pp. 4-7. Oyer (2008), pp.278-287.

${ }^{6}$ Farber and Gibbons (1996), p. 1017.

${ }^{7}$ Gathmann and Schoenberg (2010), pp. 10-36.

${ }^{8}$ Fallon and Layard (1975), p. 295. Goldin and Katz (1998), pp.710-723.

${ }^{9}$ Based on the NLSY, Parent (2000), pp. 308-320, shows that industry-specificity has larger impact on wages
} 
investment in general human capital. If complementarity between schooling and industryand/or firm-specific skill is sufficiently weak to be dominated by employer learning effect, then the interaction between schooling and tenure in the firm is expected to be non-increasing over time.

While employer learning model is entitled as "public" learning model, its prediction in fact seems to better fit with employer learning process within internal labor market of large firms from the viewpoint of dynamics of workers investment in human capital, instead of the competitive outside market. The employer learning prediction has possibly captured wage growth distorted by internal labor market of large firms.

Indeed, succeeding close interest in the original employer learning model, Galindo-Rueda (2003), Schönberg (2007), Pinkston (2009) are conscious of a possible asymmetry in employer learning and thus particular effect of tenure in total experience, Bauer and Haisken-DeNew (2001) deals with human capital investment complementary to schooling, and Baker, Gibbs and Holmstrom (1994b) and Lluis (2005) deal with wage dynamics of internal labor markets. Knitting up these three attractive strands, this research tries to distinguish learning effects in wage growth in and out of internal labor market effect, using panel data of the Japanese steel industry exactly at the time when it introduced internal labor market policy.

\subsection{Technology, skill, and organization}

Desirable structure of organization depends on prevalence of relevant information, and technological conditions shape informational structure. Technological changes affect organizational structure in this way. It particularly holds for labor organization within a firm. Technological changes affect type of necessary skill, and it could determine which player, either employees or the firm, knows the skill better. If the firm knows better about necessary skill, then direct control of labor organization could provide employees with better incentives. Given technology, skill and information structure, a firm chooses a better organization to reduce loss from asymmetric information. In other words, through the firm's decision, combination of technology, skill, and informational structure shapes labor organization. Internal labor market is a potential candidate when a firm knows necessary skills well and the skills are complementary to each other and/or firm-specific. ${ }^{10}$

Internal labor markets characterized by long-term employment and internal promotion are widely seen for high-skilled workers of large companies in developed economies. Labor organizations of white-collar employees and high-class engineers are not uniquely determined by

than firm-specificity alone, which intuitively persuasive to us as a wage earner and seems to be applicable to other economies than the US. In addition, Weinberg (2001), pp.236-247, verifies that industry specificity does shield wages from exogenous shocks. Then, Poletaev and Robinson (2008), pp. 402-413, extracts impact of skill-specificity on wages, embedded in industry-specificity. At the same time, Shaw and Lazer (2008), pp. 717720, extracts specific productivity gain of tenure at a specific firm, which implies the existence of firm-specific human capital and the relevancy of that at least to some extent. Therefore, more correctly, we had better state that internal labor market of a specific firm exists and it consists of industry-specificity and specific composition of skills. For simplicity, we tentatively skip the logical step here.

${ }^{10}$ Doeringer and Piore (1971), pp. 1-7. Williamson, Wachter and Harris (1975), pp. 269-277. Milgrom and Roberts (1992), pp. 358-385. 
technology and are often firm-specific, so internal labor markets are widely applied on whitecollar employees and engineers. It is also introduced for ordinary blue-collar employees of manufacturing in some industries where systematic procedures are required typically as in steel, petroleum refineries, paper mills, and so on. ${ }^{11}$ These industries, at the same time, are the very ones which Goldin and Katz (1998) asserts have grown with technology-skill/education complementarity since the early 20 th century. ${ }^{12}$

Empirical and descriptive works on the issue in the last two decades have rejected the traditional conjecture that, either in the US and in Japan, the internal labor market implies wage dynamics irrelevant to performance or merit. Rather, it is a evaluation device as a second best approach to make wages sensitive to performance of employees and to give employees incentives of investment in industry- and/or firm-specific human capital under asymmetric information. Thus it is expected the wages do not depart market price equal to marginal productivity in the long term on average, though they are not necessarily one-to-one equal in the short term. ${ }^{13}$

Japanese manufacturing, led by the steel industry as in the US, headed that way in the 1920s, and after the Second World War, developed even more internal-labor-market-oriented. Then "life time employment" came to be known as a feature of the Japanese manufacturing. As the US firms of good performance has continuously managed long-term employment, ${ }^{14}$ it is not a unique culture of Japanese firm, while it is true that post-war Japanese firms have more steeply tilted to long-term employment and wage growth with tenure. ${ }^{15}$ The point is arguably in that Japan experienced a faster and deeper transition of the same direction shared with other developed economies.

\subsection{Transformation in the steel industry}

Different from typically 20th century industries like petroleum refineries, transition to the internal labor market of major industries with longer tradition was accompanied by dissolution of autonomous intermediary labor organization into well organized labor organization directly and systematically planned by firms, as pointed out by the radical economists and then redefined as transition to a more efficient second best organization by new institutional economists. ${ }^{16}$ Such a transition would proceed with technological transition that provides firms with informational advantages in acquisition of relevant human capital, which makes direct control by the firm relatively efficient.

\footnotetext{
${ }^{11}$ Doeringer and Piore (1971), pp. 6, 50-51, 58.

${ }^{12}$ Goldin and Katz (1998), pp. 707-716.

${ }^{13}$ Alexander (1974), pp. 74-83, Aoki (1988), pp. 54-60. Baker, Gibbs and Holmstrom (1994a), pp. 881-884. Baker and Holmstrom (1995), pp. 256-257.

${ }^{14}$ Hall (1980), pp. 97-107. Hall (1982), pp. 719-720. A measure of the importance of long-term employment in human capital investment is relative impact of tenure at a firm and total work experience on wages. Abe (2000) shows based on the data of the 1980s that tenure alone had considerable impact on wages in the US while relative importance of tenure over experience is indeed larger in Japan than in the US (Abe (2000), pp. 261-264.).

${ }^{15}$ Hashimoto and Raisian (1985), pp. 721-732. Aoki (1988), pp. 59-69. Mincer and Higuchi (1988), pp. 112115. Moriguchi (2003), pp. 640-652. While mobility of younger generations have increased since the 1990s, long-term employment is still prevailed practice among large Japanese firms. Ono (2010), pp. 13-22.

${ }^{16}$ Marglin (1974), pp. 60-81. Stone (1974), pp. 128-147. Williamson (1985), pp. 206-239.
} 
As to the Japanese steel industry, big two phases of technological transition were seen in the 1920s and in the 1950s as larger open-hearth furnaces were introduced, and in the 1960s when converter furnaces were introduced under the American influence. Along with the technological transition, traditional skill ascriptive to individual senior employees was transformed to the skill manualized and known to the management. ${ }^{17}$ As with in the American steel industry, ${ }^{18}$ it was the core in the transition to frame a work organization with systematic wage and promotion scheme.

This paper deals with wage growth of blue-collar employees from 1929 to 1969 of the Kamaishi Iron Works, ${ }^{19}$ a leading iron works then in Japan, and approaches to wage dynamics during formation of internal labor market. To be analyzed is micro data of 1490 employees of the Kamaishi Iron Works.

The section 2 presents the estimation model. The section 3 describes the data and then verifies existence of internal labor market at the case firm. The section 4 gives empirical results.

\section{Estimation model under internal labor market effect}

\subsection{Employer learning}

Consider a random effect model of panel least square regression of $i$ th employee's wage $(w)$ at time $t$,

$$
w_{i, t}=\alpha_{0}+\alpha_{2} \operatorname{yos}_{i}+\alpha_{2} \operatorname{yos}_{i} \times t+\alpha_{3} t+\zeta_{i}+\epsilon_{i, t},
$$

where $\operatorname{yos}_{i}$ stands for years of schooling that is observable to employer and stochastic $\zeta_{i}$ captures time-invariant characteristics unobserved by the employer.

And put

$$
\Delta_{t} w_{i, t}=\alpha_{2} \operatorname{yos}_{i}+\alpha_{3}+\Delta_{t} E\left(\zeta_{i} \mid \operatorname{yos}_{i}, t-1\right)+\Delta_{t} \epsilon_{i, t} \equiv \alpha_{2} \operatorname{yos}_{i}+\alpha_{3}+\varphi_{i, t},
$$

where $\varphi_{i, t}$ is shock in the $t$ th year.

Then inference based on the public learning model by Farber and Gibbons (1996) and Altonji and Pierret (2001) brings a straightforward prediction as a benchmark. ${ }^{20}$ Linear projection of $w_{i, t}$ gives

$$
\begin{aligned}
E\left(w_{i, t} \mid \operatorname{yos}_{i}\right) & =\hat{\alpha}_{0}+\hat{\alpha}_{1} \operatorname{yos}_{i}+\hat{\alpha}_{2} \operatorname{yos}_{i} \times t+\hat{\alpha}_{3} t \\
& =\hat{\alpha}_{0}+\hat{\alpha}_{1} \operatorname{yos}_{i}+\frac{\operatorname{Cov}\left(w_{i, t}, \operatorname{yos}_{i} \times t\right)}{V\left(\operatorname{yos}_{i} \times t\right)} \operatorname{yos}_{i} \times t+\hat{\alpha}_{3} t \\
& =\hat{\alpha}_{0}+\hat{\alpha}_{1} \operatorname{yos}_{i}+\frac{\sum_{\tau=2}^{t} \operatorname{Cov}\left(\varphi_{i, \tau}, \operatorname{yos}_{i} \times \tau\right)}{V\left(\operatorname{yos}_{i} \times t\right)} \operatorname{yos}_{i} \times t+\hat{\alpha}_{3} t .
\end{aligned}
$$

\footnotetext{
${ }^{17}$ In the case of department of maintenance, the Kamaishi Iron Works, intangible knowledge that had bee inherited from senior workers to younger workers was made standardized, written as a rich manual and controlled by the firm in the early 1970s. Nakamura (2010), pp. 24-25.

${ }^{18}$ Novack and Perlman (1962), pp. 339-347. Stone (1974), pp. 128-136. Williamson (1985), pp. 234-236.

${ }^{19}$ belonged to Fuji Iron and Steel Corporation then, now belongs to Nippon Steel Corporation.

${ }^{20}$ Farber and Gibbons (1996), pp. 1010-1018. Altonji and Pierret (2001), pp. 316-323.
} 
First, if schooling and experience are complements $\left(\partial^{2} y /(\partial \operatorname{yos} \partial \tau)>0\right)$, then $\operatorname{Cov}_{i}\left(\varphi_{i}, \operatorname{yos} \times\right.$ $\tau)>0$, and otherwise $\operatorname{Cov}_{i}\left(\varphi_{i}, \operatorname{yos} \times \tau\right)=0$, for each $\tau(\tau=2, \ldots, t)$. Second, if the employer learns employees' characteristics hidden when recruiting, which is captured by $\zeta_{i}$, then $\operatorname{Cov}_{t}\left(\varphi_{t}\right.$, yos $\left.\times t\right)=0$ for each $i$.

Suppose that wages, with marginal productivity, increase over experience and standardize variables by taking logarithmic terms. ${ }^{21}$ Then, predicted are,

(a) If the employer learns employees' hidden characteristics over time, and if schooling and experience are not complements or the effect of their complementarity is dominated by that of employer's learning, then $\hat{\alpha}_{2}$ is expected to be negative. ${ }^{22}$

(b) If schooling and experience are complements and the the effect of complementarity dominates that of the employer learning, then $\hat{\alpha}_{2}$ is expected to be positive.

Based on the National Longitudinal Survey of Youth of the US, empirical evidences to support (a) have been presented. ${ }^{23}$ It is also doomed that employer learning progresses fast especially in the first few years. ${ }^{24}$

\subsection{Employees' incentives, asymmetric learning, and diversified labor markets}

This prediction of employer learning does not explicitly consider workers' dynamic decision making of ivestment in human capital. Workers are reasonably expected to choose workplaces to maximize lifetime income, given their educational background. While both of the schooling market and the labor market have frictions, friction with choice of schools seems to be much larger. ${ }^{25}$ It was the case especially prewar Japan where public elementary and secondary schools were dominant, and districts of elementary schools were determined by the government as they are now. Thus typically young people enrolled in assigned schools, graduated them, and finally made their own conscious decision when they chose workplaces.

Without particular constraints, people in the competitive open market, especially under employment contracts of short-term basis, are naturally to choose work experiences such that schooling and work experiences are complements if other conditions are the same.

\footnotetext{
${ }^{21}$ While the standard wage regression of Mincer style regress logarithmic term of wage on raw level numbers, here in this research regressors are also transformed to logarithmic terms because estimation of the equation (4) with controlling all of cohort effects requires already many independent variables. The standard estimation model needs to contain squared terms of experience and tenure to allow their effects to be marginally decreasing, but adding squared terms here makes estimation results less readable. To allow experience and tenure effects to be marginally decreasing, here their logarithmic terms are used as regressors instead of squared terms of raw level.

${ }^{22}$ In the raw level term, non complementarity implies significantly zero of $\hat{\alpha}_{2}$. Standardization taking logarithmic term means, with increase of relative impact of time variant factors such as tenure, relative impact of interaction between schooling and tenure decreases over time if they are not complementary, which implies a negative sign.

${ }^{23}$ Farber and Gibbons (1996), pp. 1023-1029. Altonji and Pierret (2001), pp.329-342. Lange (2007), pp. 4-7.

${ }^{24}$ Gibbons, Katz, Lemieux and Parent (2005), pp. 698-714. Lange (2007), pp. 9-19. A similar case in Germany is presented by Lluis (2005), pp. 745-755.

${ }^{25}$ In addition, kids themselves tend to be ignorant about return of schooling as reported by Jensen (2010).
} 
This direction of human capital investment has become even more desirable since the early 20th century, as technology-skill/education complementarity has become augmented with transition of production process from artisanal shops to factory system, continuous production system, and "computerized" production line ${ }^{26}$.

On the other hand, if the current employer commits to operating internal labor market policy consisting of long-term employment and internal promotion, then the employees could have incentives to invest in industry- and/or firm-specific human capital that might be less complementary to general skills that have been taught at schools. Indeed, in the case of the US, industry-specificity of human capital obviously decrease mobility of workers, and induce firms to protect wages and employment of experienced workers against exogenous shocks more than they do to young workers. That kind of commitment is necessary to entice workers invest in industry- and/or firm-specific human capital. ${ }^{27}$

The intensity of technology-skill/educatoin complementarity and employers' adjustment to it could affect institutional arrangement in the labor market and accordingly employer learning process. In the German case, after Bauer and Haisken-DeNew (2001) found the dominant effect of complementarity between schooling and experience and rejected employer learning effect, ${ }^{28}$ Lluis (2005) succeeded in carefully mining some evidence of employer learning by controlling job-rank effects. ${ }^{29}$ The German labor market appears to be modeled as friendly to investment in general human capital, compared with those in the US, the UK, ${ }^{30}$ and Japan inquired by this research.

Another issue is the extent of asymmetry in employer learning. About the US labor market, Pinkston (2009) finds that informational structure in employer learning is asymmetrically favorable to incumbent employers and thus tenure has impact on learning additional to total experience, ${ }^{31}$ while Schönberg (2007) evaluates that the asymmetry is not so large as it affects the speed of employer learning. ${ }^{32}$ About the UK, on the other hand, as Galindo-Rueda (2003) recognizes strong evidence of employer learning, it also finds stronger learning effect of tenure, instead of total experience of workers, and asserts that incumbent employers have informational advantage in learning over entrant employers. ${ }^{33}$ As later shown on Table 3, the same effect is clearly observed in the Japanese labor market.

Diversity of labor markets consists of institutional framework that encourages human capital investment and informational structure that enables employers to learn workers' types. The coefficient of interaction term between schooling and experience is the tractable measure of employer learning. At the same time, this is a focal point of diversity of labor markets, which varies depending on institutions of human capital investment and informational structure about workers' types.

\footnotetext{
${ }^{26}$ Goldin and Katz (1996), pp. 253-256. Goldin and Katz (1998), pp. 698-719. Autor, Katz and Kearney (2006), pp. 190-191.

${ }^{27}$ Weinberg (2001), pp. 236-251.

${ }^{28}$ Bauer and Haisken-DeNew (2001), pp. 163-177.

${ }^{29}$ Lluis (2005), pp. 749-755.

${ }^{30}$ Galindo-Rueda (2003), pp. 8-17,

${ }^{31}$ Pinkston (2009), pp. 381-389.

${ }^{32}$ Schönberg (2007), pp. 672-678.

${ }^{33}$ Galindo-Rueda (2003), pp. 13-15.
} 


\subsection{Identification of the internal labor market effect in the wage growth}

With concerns about investment in human capital, workers are expected to invest in general human capital both at schools and workplaces if their employers do not commit to internal labor market policy. On the other hand, employers do not generally have incentives to invest in general human capital of employees. If any, employers willingly invest in environments favorable to accumulation of firm-specific human capital. Then employees could have incentives of investment in firm-specific human capital if their employers do commit to internal labor market policy.

To capture this effect of internal labor market that potentially slips into strings of wage determination, empirical exercise later separates $i$ th employee's experiences before and after he joined the firm that commits to internal labor market policy such as $t=e p r=p v r+$ ten, where pvr is experience before he joined the case firm, ten is tenure at the firm, and epr is total experience. Then the wage regression equation (3) is reformulated as

$$
\begin{aligned}
w_{i, t}=\beta_{0} & +\beta_{1} \operatorname{yos}_{i} \\
& +\beta_{2} \operatorname{yos}_{i} \times \operatorname{pvr}+\beta_{3 \operatorname{yos}_{i} \times \text { ten }} \\
& +\beta_{4} \mathrm{epr}+\beta_{5} \text { ten }+\boldsymbol{\gamma}^{T} \boldsymbol{x}_{\boldsymbol{i}}+\boldsymbol{\delta}^{T} \boldsymbol{x}_{\boldsymbol{i}} \times \text { ten }+\zeta_{i}+\epsilon_{i, t},
\end{aligned}
$$

where $\boldsymbol{x}_{\boldsymbol{i}}$ stands for time-invariant characteristics vector other than educational background. ${ }^{34}$

Taking logarithmic terms of variables, predictions from employer learning combined with workers' concerns about investment in human capital are,

Prediction 1. the interaction term between years of schooling and previous experience before employed by the firm (yos $\times$ pvr) is expected to have positive coefficient $\left(\hat{\beta}_{2}>0\right)$, which indicates that complementarity between schooling and work experiences is strong enough to dominate the employer's learning effect,

and,

Prediction 2. the interaction term between years of schooling and tenure after employed by the firm (yos $\times$ ten) is expected to have negative coefficient $\left(\hat{\beta}_{3}<0\right)$, which indicates that the firm learns employees' hidden characteristics over tenure, and that schooling and tenure are not complements, or the learning effect dominates their complementarity effect if any.

It is examined in the section 4.3 whether this prediction is supported or not.

\footnotetext{
${ }^{34}$ Bauer and Haisken-DeNew (2001), pp. 163-170, applies this formulation of regression on the German data to inquire whether employers' go "public"ly in the labor market (through workers' total experience) or "private"ly (thorough tenure at specific firms), and denies any employer learning effect, which is strikingly different result from the US and Japan cases. We will be back to this point in the section 5.1. Also, Schönberg (2007) adds tenure to experience as regressors in the wage regression, to inquire possible difference in learning processes of incumbent and outside employers. ${ }^{35}$
} 


\section{The case firm and the data}

\subsection{Kamaishi Iron Works on its historical context}

Kamaishi Iron Works is the oldest iron works in Japan, opened by the Nambu Domain in 1857. After nationalized in 1873 and privatized again in 1884, new blast furnaces were built and began continuous production from iron to steel in 1903. After owned by the Mitsui holdings, the largest conglomerate, in 1924, it was merged with other major iron works into Nippon Iron and Steel in 1933. The merge was coordinated by the government for technological improvement. Traditional skill required for the early 20th century technology had developed in its labor organization as it started modernization efforts in the 1930s.

Then, Japan entered the war against the US, and during the wartime isolation, Japanese steel industry turned out to be backward. After the Second World War, steel companies as well as other important manufacturing companies were induced to invest in new technology with long-term financing coordinated by the government. For the iron and steal industry, three coordinated modernization investments were planned. The "1st plan" was 1951-1954, the "2nd plan" was 1956-1960, and the "3rd plan" was 1961-1964. Through the plan, for the Kamaishi Iron Works, then an iron works of Fuji Iron and Steel, now Nippon Steel, improvement of efficiency in iron and steel production and expansion of fine steel production were emphasized, but replacement of old blast furnaces was not planned.

A big change during the modernization since the 1950s at production lines was standardization, or "manualization," of production procedures. Before the Second World War, in the iron and steal industry, sophisticated procedures of production were developed by employees and taught to younger employees by the elder. Since the 1950s, however, procedures of productions lines became manualized by better educated engineers, and the best practices at the shop floor came to be known to the firm. ${ }^{36}$

As a part of company wide investment plan, Fuji Iron and Steel decided to build a new state-of-the-art plant called Tokai in Nagoya, now an iron works of Nippon Steel. Because it was a new plant, skilled workers were not there. About iron production capacity, the firm decided to decrease Kamaishi's and to increase other new plants such as Tokai, and to relocate skilled workers of Kamaishi and other old iron works to Tokai. Then 1,678 skilled workers moved from Kamaishi to Tokai in 1964, 1967, 1968, and 1969. ${ }^{37}$

\subsection{The data}

This research uses preserved 1,490 of relocated Kamaishi employees' panel data of wages, tracking from the late 1920s or later, depending on employee, to the 1960s, when they left Kamaishi. This data set has both considerable disadvantage and advantage.

The disadvantage is about selection and survival biases. Selection for relocation was handled under close dialogue and coordination between the firm and the union, and, in principle,

\footnotetext{
${ }^{36}$ Nakamura (2010), pp. 8-21.

${ }^{37}$ With 1,678 from Kamaishi, 908 from Muroran, 972 from Hirohata, and 127 from Kawasaki were relocated. Umezaki (2010), pp. 33-38.
} 
anyone who was willing to move were accepted. Thus, there was not a clear and intended measure to select employees for relocation. ${ }^{38}$ However, it is not followed that this is an unbiased sample set. First, employees who willingly moved to Nagoya were those who believed that they would get successfully used to the most advanced plant. They were more ambitious and/or self-confident employees than average. Second, all of the sample employees were those who had worked until they moved to Nagoya in the 1960s. The "losers" in the internal competition at Kamaishi who dropped are not included. Selected employees were likely to be the employees trained to get used to new technology, and well built-in internal labor market that was formed during the technological transition.

At the same time, the data set also has advantages respectable especially for this research. Intrinsically to original personnel documents, the documents contain all important information on employees' CV when they were employed. It enables us to recover their whole life from the time when they were born to the late 1960s when they were relocated. The information includes records of previous working experiences not only educational record, and physical features such as height, weight, and lung capacity, which were thought to be important for blue-collar workers.

Each individual wage record includes:

1. Educational background (yos).

2. Physical characteristics when employed: height (hgt), weight and lung capacity.

3. Panel data of

(1) record of in-house training if the employee completed one:

- Systematic programs for those selected from newly employed employees:

1927-1935: "Youth Development Center (Seinen Kunrenjo)" (ydc). Three days a week, 4 years, 300 hours as total.

1935-1948: "School for Youth (Seinen Gakko)" (sy). Halftime, three days a week.

1939-1946: "Development Center for Technicians (Ginosha Yoseijo)" (dct). Fulltime, 3 years, 6,453 hours as total.

1946-1973: "Development Center (Kyoshujo)" (dc). Three days a week, 2 years (by 1950), 6 days a week (from 1950). From 1953, only high school graduates were admitted.

- Short term programs (ex. elementary calculus).

(2) licenses the employee held.

(3) family composition.

(4) clinical history.

(5) basic wages.

\footnotetext{
${ }^{38}$ Umezaki (2010), pp.47-49.
} 
(6) promotion and deployment: classes, division and department assignment, and job assignment. The 49 divisions, 174 departments and 110 jobs have been recorded in the total.

The panel data of the basic wage starts when the employee joined the firm, and ends at the time when he moved to the Tokai Iron Works, varying from 1964 to 1969.

Composition of cohorts is shown on Table 1. A small peak is across from 1938 to 1942, when the wartime effort hit the peak with invasion to China in earnest from 1937 and the attack to the Pearl Harbor in 1941, followed by the American backfire including carpet bombing on the city of Kamaishi, and a bigger peak is across from 1948 to 1951, when the Japanese economy began to recover from the wartime destruction.

An especially important feature of the data set is in that those who were employed immediately after graduation are not dominant, which might not look typical in Japanese firm. The recruitment practice to employ new graduates was being prevailed for blue-collar workers since the mid 1960s, and not typical at all before that time. Indeed, the mean of previous experience (years after graduating school and before being employed by the firm, pvr) is even not monotonically decreasing.

Since the late 19th century, when the heavy manufacturing was introduced from the Western world, career path of experiencing several workplaces to acquire skill and then to be employed by a large firm in the long-term basis, or to start own workshop became a typical one among skilled workers. This tradition is not only well exploited by this research strategy on the equation (4). So-called "port of entry" practice of typical "Japanese firm," under which employees are employed immediately after they graduate schools without experience at any other workplace was not prevailed for blue-collar workers even at the leading firm of the steel industry, the core industry then, in the covered period. It could allow empirical results of this research to be comparable to other industrial economies.

Compulsory education was extended from 6 years to 9 years in 1947, as shown in the minimum years of schooling on Table 1. Difference of educational background across employees who graduated before 1947 is distributed mainly between 6 years of completing mandatory elementary school and 8 years composed of mandatory 6 years and 2 yeas of completing high elementary school. Table 1 shows graduates of high elementary school were majority before $1947 .{ }^{39}$ Difference of employees who graduated after 1947 is distributed mainly between the mandatory 9 yeas of elementary school (6 years) and junior high school (3 years) and the 12 years of mandatory 9 years plus additional 3 years of high school. High school graduates were minority still in the 1960 s.

\subsection{Verifying existence of internal labor market}

Before estimating the equation (4), the existence of internal labor market policy, which somehow "shields" wage determination from the outside market, itself to be empirically established. We basically follow the strategy presented by Baker et al. (1994b).

\footnotetext{
${ }^{39}$ Already in the 1920 s, major factories of heavy industry had preference of graduates of high elementary schools to those of elementary schools, especially for candidates of foremen. Sugayama (2011), p. 37.
} 
If a firm offers competitive wages to revealed characteristics such as educational background of prospective employees in the market when the firm recruits workers, and if the firm adopts internal labor market policy under which wages are determined based on internal rules or evaluation that not more or less "shield"s internal wage dynamics from the market price, then wage growth of each cohort could share common trend "shiled"ed from the market price. Thus survival of cohort effect is a useful indicator of existence of internal labor market that somehow "shields" wage determination from the outside price mechanism at each point, ${ }^{40}$ though it does not imply wage that the dynamics deviates the market price in the long term.

Table 2 contains regression of real daily wages (rw) on experience in the labor market (epr), tenure (ten), years joined dummy (yj), and interaction between years joined dummy and tenure $(\mathrm{yj} \times$ ten). To control composition effect of educational background varying over cohorts, years of schooling (yos) is also inserted as a regressor. The period saw a rapid growth of average productivity, which is controlled by year dummies. On the model 1-2, to allow marginally decreasing of cohort effect, interaction term of years joined dummy and tenure $(y j \times$ ten $)$ is inserted as a regressor instead of tenure (ten). ${ }^{41}$

Cohort effects generally survive among employees of all cohorts. The internal labor market at the Kamaishi Iron Works seems to have been formed in the 1930s. This statistical inference is consistent with descriptive picture based on documents and hearings. ${ }^{42}$

Thus the basic wage at the first year shows the open market price of his labor, and the growth of the basic wage in the following year shows the firm's evaluation of his labor based on some internal measures.

In addition, wage rw shows obvious serial correlation. Auto regression with random effects of real wage $\left(\mathrm{rw}_{\mathrm{ten}}\right)$, with years of education $\left(\mathrm{yos}_{i}\right)$ and year dummies inserted, gives, ${ }^{43}$

$$
\log \mathrm{rw}_{\text {ten }}=\underset{21.6217^{* *}}{0.3424}-\underset{16.1141^{* *}}{0.0080 \mathrm{yos}}+\underset{354.7567^{* *}}{0.8426} \log \mathrm{rw}_{\text {ten }-1},
$$

where absolute value of the coefficient of lagged term $\left(\mathrm{rw}_{\mathrm{ten}-1}\right)$ is smaller than 1 , which means each history of wage is a contraction mapping. ${ }^{44}$ Thus each wage history is heading for somewhere stationary.

Furthermore, a regression of real wage on more lagged terms gives with random effects

\footnotetext{
${ }^{40}$ Baker et al. (1994b), pp. 923, 933-940. Baker and Holmstrom (1995), pp. 258-259.

${ }^{41}$ Our approach differs from Baker et al. (1994b) in some important points. In order to avoid identification difficulty but to extract cohort effect, Baker et al. (1994b) assumes that tenure effect on wage growth is linear and estimates the coefficient of linear regression of wages on tenure, deducts the estimated tenure effect from cohort average wage, and regress this adjusted cohort average wage on cohort dummies. However, tenure effect is not necessarily linear in general. Also, two-staged estimation seems to have cohort effect appear larger than real. Hence, to deal with identification problem, we simply bind adjacent two cohorts together into one group, and then regress wages on two-cohort groups.

${ }^{42}$ Umezaki (2010), pp. 42-51.

${ }^{43}$ Estimation: Panel estimated generalized least squares with cross-section random effects. Year dummies: Yes. Sample periods: 40 (1930-1969). Cross-sections included: 1,482. Total panel observations: 20,511. The $t$ statistics are within parentheses, where $* *$ stands for significance smaller than 1 percent. Adjusted $R^{2}: 0.9691$. $F$-statistic: $15,706.8328^{* *}$.

${ }^{44}$ It implies that extended growth curve of wage has unique fixed point.
} 
and year dummies gives, ${ }^{45}$

$$
\begin{aligned}
& \log \mathrm{rw}_{\mathrm{ten}}=\underset{\left(21.2829^{* *}\right)}{0.3338}-\underset{0.7289^{* *}}{0.0004 \mathrm{yos}} \\
& +\underset{\left(52.8953^{* *}\right)}{0.4450} \log \mathrm{rw}_{\text {ten }-1}+\underset{\left(17.6055^{* *}\right)}{0.1485} \log \mathrm{rw}_{\text {ten }-2} \\
& +\underset{\left(9.0439^{* *}\right)}{0.0765} \log \mathrm{rw}_{\text {ten }-3}+\underset{\left(7.4901^{* *}\right)}{0.0592} \log \mathrm{rw}_{\text {ten }-4} \\
& +\underset{\left(8.4776^{* *}\right)}{0.0640} \log \mathrm{rw}_{\text {ten }-5}+\underset{\left(5.5702^{* *}\right)}{0.0394} \log \mathrm{rw}_{\text {ten }-6} \\
& +\underset{\left(5.1365^{* *}\right)}{0.0332} \log \mathrm{rw}_{\text {ten }-7}+\underset{\left(4.8108^{* *}\right)}{0.0226} \log \mathrm{rw}_{\mathrm{ten}-8} .
\end{aligned}
$$

While the past has significant impact on the current wage growth, the impact is monotonically decreasing, with each wage history going to some stable phase. ${ }^{46}$

Periods in concern saw rapid growth of labor productivity in the industry, hence average wage accordingly rapidly grew on average. On the equations (5) and (6), however, the effect is controlled by the year dummies inserted.

Therefore, followed from serial correlations seen on the equations (5) and (6), first, the sample employees are heterogeneous and there were "systematic winners and losers" 47 probably due to different ability of human capital accumulation, ${ }^{48}$ and second, wage dynamics is on trajectory to some steady state, which is supposed to be true value of the employee's "latent" ability. Though this process with serial correlation is not directly drawn from the "pure" employer learning model, it is consistent with secondary story derived from the employer learning model. If the employer, for instance, uses accumulated information for assignment of employees, then such a regularly serial correlation could be observed ${ }^{49}$

Thus the monotonic shape of trajectory is at least partly due to the employer's learning process.

\section{Empirical results}

\subsection{Overview: Tenure, employer's learning, and in-house training}

Before directly going to estimation of the equation (4), let us give an overview based on the ordinary regression equation (3). Table 3 gives results of random effect estimation regressing real wage (rw) on height when employed by the firm (hgt), years of schooling the employee

\footnotetext{
${ }^{45}$ Estimation: Panel estimated generalized least squares with cross-section random effects. Year dummies: Yes. Sample periods: 33 (1937-1969). Cross-section included: 1,093. Total panel observations 11,393. Adjusted $R^{2}$ : 0.9623. $F$ statistic: $7099.4704^{* *}$.

${ }^{46}$ Absolute values of all real roots of $1-0.4450 z-0.1485 z^{2}-0.0765 . z^{3}-0.0592 z^{4}-0.0640 z^{5}-0.0394 z^{6}-$ $0.0332 z^{7}-0.0226 z^{8}=0, z=-1.8900,1.0476$, are greater than 1 , which implies the auto-regression equation (6) is stationary as the equation (5) is.

${ }^{47}$ Baker and Holmstrom (1995), p. 257. The result is theoretically predicted by symmetric learning of the employer and the employee (Gibbons and Waldman (1999), pp. 1333-1341.).

${ }^{48}$ Baker et al. (1994b), p. 947.

${ }^{49}$ Baker et al. (1994b), pp. 924, 926-927.
} 
had completed (yos), experience in the labor market (epr), tenure at the firm (ten), interaction of height and experience (hgt $\times$ epr), interaction of height and tenure (hgt $\times$ ten), interaction of years of schooling and experience (yos $\times$ epr), interaction of years of schooling and tenure (yos $\times$ ten), dummy variables of completing in-house training programs, Development Center for Youth (dcy, operated in 1927-1935), School of Youth (sy, operated in 1935-1948), Development Center for Technicians (dct, operated in 1939-1946), Development Center (dc, operated in 1946-1973), interaction of them and tenure $($ dcy $\times$ ten, sy $\times$ ten, dct $\times$ ten, $\mathrm{dc} \times$ ten). ${ }^{50}$ The compulsory schooling was extended rom 6 years of elementary school to 9 years of 6-year elementary school and 3-year junior high school in 1947. Since extension of compulsory schooling could have big impact of wages, ${ }^{51}$ the postwar education generation dummy (psw) is inserted.

Tenure is robustly significant in all regressions. Experience within the firm strongly contributed to wage growth. At the same time, the employer learning hypothesis strongly holds when the data set handled as a whole. On Table 3, interaction terms of years of schooling both with experience after graduation (yos $\times$ epr) and tenure (yos $\times$ ten) are significantly negative in the models of 3-2 and 3-4. Negatively significant coefficient of yos $\times$ ten indicates that the current employer learned better than previous employers, as the British case. ${ }^{52}$

As well as years of schooling, a proxy of ability observable to the employer when employed is physical characteristics such as height. Height is thought to sometime affect wages sometime, ${ }^{53}$ while the channel is still ambiguous especially for white-collar workers. ${ }^{54}$ In the case of blue-collar workers in the steel industry, the industry of masculine then, however, the physical strength was definitely critical especially in the department of pig iron production where workers required to be tough against extremely high-temperature and to still make difficult decision about how to manage blast-furnace that determined the quality of pig iron, the raw material of high-value-added of fine steel. Thus height is a good proxy of physical strength. Again, also about height, the employer's learning hypothesis holds. Interaction terms of height with tenure (hgt $\times$ ten) has significantly negative coefficient in the models 3-3 and $3-4$.

\subsection{Schooling and in-house training programs}

Table 3 also shows that role of training programs changed over time. The interaction of postwar program with tenure ( $\mathrm{dc} \times$ ten) has significantly negative coefficient while the interaction terms of prewar programs with tenure $(\operatorname{dcy} \times$ ten, sy $\times$ ten, det $\times$ ten) have significantly positive ones in the models 3-1, 3-2, 3-3, and 3-4.

All of Development Center for Youth, School of Youth, Development Center for Technicians, and Development Center were operated exclusively for newly employed employees at entry-level. As some of entry-level employees were chosen, the employer had not yet learned

\footnotetext{
${ }^{50}$ Some samples lack the information of height, weight, and lung capacity.

${ }^{51}$ Oleopoulos (2005), pp. 158-170.

${ }^{52}$ Galindo-Rueda (2003), pp. 13-15.

${ }^{53}$ Hersch (2008), pp. 369-375.

${ }^{54}$ Kuhn and Weinberger (2005), pp. 418-420.
} 
hidden types of employees and the firm likely used some proxy to choose trainees from newly employed employees. In particular, the change in sign of interaction terms from prewar the programs (dcy, sy, dct) to the postwar program (dc) can be attributed to selection policy of Development Center (dc), which admitted only high school graduates since 1953. Closely linked to educational back ground, the effect of in-house training program also came to decrease over time as the employer learned types of employees hidden when employed.

\subsection{Internal labor market effect}

The empirical overview so far has established that employer learning hypothesis saliently holds particularly after employed as interactions of years of schooling and height with tenure (yos $\times$ ten, hgt $\times$ ten) have significantly negative coefficients. Next we proceed to extraction of some information about interaction between employees' history before employed by the firm and wages.

Now examine the equation (4) and the drawn Prediction 1. and Prediction 2. in the section 2.3. Table 4 presents a regression of real wage (rw) on years of schooling (yos), experience after graduation and before employed by the firm (pvr), tenure after employed by the firm (ten), interaction of cohort dummy, years of schooling and previous experience before employed by the firm $(y j \times$ yos $\times$ pvr), interaction terms of cohort dummy, years of schooling and tenure $(y j \times$ yos $\times$ ten), with controlling training programs (dcy, sy, dct, dc), interaction terms between training programs and tenure (dcy $\times$ ten, sy $\times$ ten, dct $\times$ ten, dc $\times$ ten), and interactions between year dummy and years of schooling (dy $\times$ yos) to capture changes in return of schooling over the period.

Then, except for early cohorts up to the mid 1930s, interaction term between years of schooling and tenure (yos $\times$ ten) has significantly negative coefficients also here, which supports the employer learning hypothesis by Farber and Gibbons (1996) and Altonji and Pierret (2001) as well as the Prediction 2. in the section 2.3. However, interaction of years of schooling and previous experience (yos $\times$ pvr) has significantly positive coefficient, which violates the employer learning hypothesis and supports the Predictions 1. of workers behavior in human capital ivestment in the section 2.3.

An immediate interpretation of the result on Table 4, considering average years of previous experience on Table 1, is that workers had chosen workplace experiences given their educational background such that they were in fact complementary to schooling before employed by the firm in the first several years in their job career, and, after employed by the firm, invested in firm-specific human capital not necessarily complementary to schooling, as the firm also learned employees' ability that was not indicated by educational background. Workers invested in general human capital at schools and workplaces before they joined the internal labor market, and turned to investment in human capital less complementary to schooling after they joined. This is a story consistent with the result.

While regression of wages on the interaction term between years of schooling and experience $($ yos $\times$ epr) on Table 3 suggests that employer learning holds, the results on Table 4 indicates that coefficient of the interaction term between years of schooling and experience $($ yos $\times$ epr) could be divided into two effects of before and after employed by the firm 
(yos $\times$ pvr, yos $\times$ ten), whose coefficients' signs are opposite.

Employer learning is assumed to be "public" learning in the competitive labor market (Farber and Gibbons (1996)). However, the result here, along with Galindo-Rueda (2003) and Pinkston (2009), shows that learning effect does not dominate complementary effect of schooling and experience as workers invested in general capital in their early stages of career. Employers' learning is observed rather after workers joined the internal labor market and were separated from the competitive market, instead of "public"ly going through the competitive market. Interaction term between years of schooling and experience (yos $\times$ epr) on Table 3 appears to support employers' learning, but it is not because the workers ability came to be "public"ly learned in the market over time, but because results are affected by employer's learning and corresponding promotion of employees after incorporated to the internal labor market.

Indeed, coefficient of the interaction term between years of schooling and previous experience $($ yos $\times$ pvr) is significantly positive, as that between years of schooling and experience after employed by the firm (yos $\times$ ten) is significantly negative on Table 4 . Because the latter effect is dominant, it appears, coefficient of interaction between years of schooling and experience (yos $\times$ epr) on Table 3 is negative. In this sense, significantly negative coefficient of the interaction term between years of schooling and and experience (yos $\times$ epr) seems to capture an effect of the internal labor market.

\section{Discussion: implication of the empirical result}

\subsection{Identification of internal labor market effect and comparative anal- ysis of labor markets}

As employers' learning hypothesis assumes learning is publicly going in the labor market, previous empirical studies such as those based on NLSY have not differentiated employers' learning outside and within the firm (Farber and Gibbons (1996), Altonji and Pierret (2001)). On the other hand, the representative works of modern approach to the internal labor market does not provide clear answer to the mixed picture, which partly supports employers' learning, on-the-job training, or comparative advantage hypotheses (Baker et al. (1994b), Gibbons et al. (2005), Lluis (2005)).

Some empirical evidences indicate that long-term employment is seen and does have positive impact wages and job protection on in the American workplaces, to encourage industry-, firm-, and/or skill-specific human capital. ${ }^{55}$ In addition, since the 1930s, basic wages of American workers in fact have been even more shielded to exogenous demand shocks than Japanese and British counterparts due to institutional settings of the labor market, ${ }^{56}$ and some empirical results support the existence of implicit contract to shield wages from macroeconomic shocks

\footnotetext{
${ }^{55}$ Hall (1980, 1982). Abe (2000), pp. 258-263. Weinberg (2001), pp. 236-251. Poletaev and Robinson (2008), pp. 400-413.

${ }^{56}$ American firms seem to adjust workdays instead of basic wages to demand shocks. Gordon (1982), pp. $18-42$.
} 
in the US. ${ }^{57}$.

Furthermore, exactly based on NLSY, Parent (1999) shows, first, current employers reward on-the-job training completed with themselves, second, current employers also reward onthe-job training their employees completed with previous employers, and third, employees who completed on-the-job training with current employers have lower separation rate..$^{58}$ The result mentions that young American workers join long-term basis employment after they accumulate experiences to be appreciated by the last employer.

Moreover, conjecture of employer learning in early stages has succeeded in provision of concrete result empirical studies in an intra-firm data $\operatorname{set}^{59}$ while a study based on NLSY, which include mixed ingredients of employees who are already incorporated into long-term employment and yet to be gives much less clear result. ${ }^{60}$ Also here in intra-firm data of Japanese steel industry, the faster employer learning the earlier stage principle is presented very clearly on Table 4, as later cohorts, which capture employer learning effects on early stages, show larger absolute value of negative coefficients of interaction term between years of schooling and tenure (yos $\times$ ten).

Along with the evidences, this case study suggests probability that existent empirical results to support the employers' learning has been affected either by the effect of incumbent employers' asymmetric learning or by investment in industry- and/or firm-specific human capital, instead of symmetric learning in the competitive labor market.

The extent of asymmetry of employer learning, and the extent of complementarity between schooling and experience could vary over economies, of course. As Galindo-Rueda (2003), Schönberg (2007) and Pinkston:2009 mention that employer learning goes a little more symmetrically in the US than in the UK. ${ }^{61}$ Also, investment in human capital in Germany inquired by Bauer and Haisken-DeNew (2001) seems to concentrate in industry-specificity instead of firm-specificity even more than in the US labor market studied by Weinberg (2001) ${ }^{62}$ If skill is perfectly standardized within each industry different from the US, and if secondary schooling emphasizes vocational education for specific industries more, instead of liberal arts, then skill is almost always general to the most workers who do not change industry in their life courses and schooling and work experience are intrinsically complements.

Compared with the presented evidences for the US, the UK, and Germany, the result of this research mentions that the Japanese labor market in the early half of the 20th century was closer to the contemporary British than to the contemporary American, in terms of symmetry of informational structure for employer's learning, and closer to the contemporary American than to the contemporary German, in terms of comparative emphasis on industry- or firmspecificity of human capital investment.

\footnotetext{
${ }^{57}$ Beaudry and DiNardo (1991), pp. 675-685. Similar results for Canada are presented by McDonald and Worswick (1999), pp. 886-888. The same institutional setting of "shielding" could make wages sensitive to the employer's prosperity instead of the market and thus serial correlational, as shown by Dohmen (2004), pp. 746-752.

${ }^{58}$ Parent (1999), pp. 305-315.

${ }^{59}$ Lluis (2005), pp. 745-755.

${ }^{60}$ Gibbons et al. (2005), pp. 698-714.

${ }^{61}$ Galindo-Rueda (2003), pp. 13-15. Schönberg (2007), pp. 672-675, Pinkston (2009), pp. 381-389.

${ }^{62}$ Weinberg (2001), pp.236-247. Bauer and Haisken-DeNew (2001), pp.166-177.
} 
To proceed such a comparative analysis, further inquiry based on panel data of employees who work for specific firms is desired. In this sense, the literature following Lluis (2005) that focused on employer learning and matching within internal labor markets are hoped to be enriched, and this case study hopefully is one of them.

\subsection{Learning in early stages}

Table 4 also shows tnhat coefficient of interaction between years of schooling and tenure and yos $\times$ ten decreases as cohort goes down. It indicates that employer's learning went faster in the late periods. Since later cohorts have shorter tenure, employer's learning effect observed with later cohorts show employer's learning in the first few years. Lluis (2005) infers that learning effect had larger impact in earlier tenure in internal labor markets, based on the German data. ${ }^{63}$ The result here is consistent with the inference.

\subsection{Schooling, internal labor market, and dual structure}

After the Second World War, the Japanese government extended mandatory schooling from 6 years to 9 years, and the number of high schools drastically increased. The explosive expansion of secondary schooling, which proceeded in the 1920s in the US, occurred in Japan from the 1950s to the 1960s. Secondary school system in prewar Japan, introduced from Europe, was the one to train a small group of elites. It was completely transformed into massive investment in human capital of majority people, which was a case of convergence to the American system of secondary education, along with convergence to the US-led technology-skill complementary development. ${ }^{64}$

Postwar junior high schools and most of high schools have focused on general education, not vocational education concentrating on particular and inflexible skills. The "uniquelyAmerican invention" 65 of extended secondary school in the early 20th century was introduced to Japan after the Second World War, accompanied with rapid increase of capital-labor ratio, in the economic race to catch up with the US. ${ }^{66}$ It directly led to supply of higher educated blue-collar labor force to the manufacturing sector. In despite of the rapid increase of better educated workers, the significantly positive coefficient of postwar education dummy (psw) on Table 3 shows that return of schooling rather increased after the Second World War. ${ }^{67}$

\footnotetext{
${ }^{63}$ Lluis (2005), pp. 745-755.

${ }^{64}$ Goldin (2001), pp. 269-275. Ueshima, Funaba and Inoki (2006), pp. 72-73.

${ }^{65}$ Goldin (1998), p. 350.

${ }^{66}$ Godo and Hayami (2002), pp. 968-974.

${ }^{67}$ This is mainly because coverage of this research is up to the 1960 s. An empirical study on the manufacturing sector as a whole indicates that wage premium with graduation of high school or more hit the highest in the mid 1960s, and had gradually declined since then (Ohkusa and Ohta (1994), p. 180-181). Ueshima (2003) argues that the educational wage differential was squeezed by rapidly increased supply of high-school graduates (Ueshima (2003), pp. 47-48.), as it was in the US in the mid 20th century, though institutional factors had a significant role in the US (Goldin and Margo (1992), pp. 17-32. Goldin (1999), pp. s80-s92.). As the most of a cohort came to enrol high school by the end of the 1970 s, and the educational wage differential became an issue between college graduates and high school graduates. In the 1980s, while wage differential between college and high school graduates rose astonishingly in the US, the rise in Japan was relatively modest (Katz and Revenga (1989),
} 
It indicates that, responding to increased supply of higher-educated workforce, technologyskill/education complementarity was augmented along with manualization of production line, and the transition rather increased demand for more educated workers and pulled up return on education, ${ }^{68}$ as happened in the US from the 1920 s to the $1940 \mathrm{~s} .{ }^{69}$ Also, massive ivestment in public education by the government apparently succeeded in release of the society from the "low skill trap" equilibrium. ${ }^{70}$ As result, productivity of the Japanese manufacturing sector is estimated to overtake the British in the 1970s, and the German in the 1980s, closing the gap with the American though still behind. ${ }^{71}$

The Kamaishi Iron Works took the trend and invested more in higher educated workers after the Second World War, as the negative coefficient of interaction between years of schooling and Development Center dummy (yos $\times$ dc) on Table 3 mentions.

While "port of entry," where only young workers are employed and are assigned to the lowest ladder, is a symbolic feature of internal labor market suggested by Doeringer and Piore (1971), it is not always empirically supported. ${ }^{72}$ In the case of Japanese manufacturing, it became a dominant practice in the 1960s, much later than formation of internal labor market in the 1930s. It had become a common practice of personnel management of major firms to hire new graduates and apply internal promotion not only for white collar employees also for blue collar employees in the $1960 \mathrm{~s},{ }^{73}$ and on-the-job training closely linked educational background became a persistent personnel policy in Japanese firms. ${ }^{74}$ More investment in freshmen who had just graduated high school at Kamaishi was a part of this prevailed trend.

This analysis of the micro data is consistent with the story "dual" labor market of the Japanese manufacturing in the macroeconomic context: Better educated graduates get into major firms, and, while internal labor market was dominant among major factories with advanced technologies such as the Kamaishi Iron Works, it was not among small and medium sized firms. Better education and investment in firm-specific human capital brought higher wages. Once an employee left a major firm, he could get only in small or medium sized firms with lower technology that paid worse. The quasi-rent provided employees of major firms with strong incentives to commit to internal labor market. This structural feature is thought to have emerged in the 1920 s and had been persistent in the 1980 s. $^{75}$

As manufacturing firms began to form internal labor market with modernization effort,

pp. 526-535.). Katz and Revenga (1989) suggests that it was at least partly because high school graduates in the Japanese manufacturing were better adjusted to technological changes with support from on-the-job-training enhanced in Japanese firms (Katz and Revenga (1989), p. 545.), which is a consistent with the result that relative importance of tenure over total experience is larger in Japan (Abe (2000), p. 264.).

${ }^{68}$ This possible story is consistent with the theoretical prediction such as Kiley (1999), pp. 712-720.

${ }^{69}$ Goldin and Katz (1998), pp. 726-727.

${ }^{70}$ Burdett and Smith (2002), p. 1450.

${ }^{71}$ Broadberry (1994), pp. 292-295.

${ }^{72}$ Doeringer and Piore (1971), pp. 43-48. Baker and Holmstrom (1995), p. 256.

${ }^{73}$ Gordon (1985), pp. 386-411. Sugayama (2011), pp. 338-443.

${ }^{74}$ Higuchi (1994), pp. 172-174.

${ }^{75}$ Ujihara (1966), pp. 402-425. Chuma (1998), p. 262. Ishikawa (2001), pp. 241-282. Odaka (2003), pp. 126-136. The more educated, the longer tenure is still the dominant principle among large Japanese firms. Ono (2010), pp. 13-17. As a heritage of the structure, for instance, "sheepskin" effect is much smaller in small firms. Bauer et al. (2005), pp. 
the government increased investment in public education. Workers invested in general human capital at schools and short-term employment, and in firm-specific human capital in internal labor market. The society-wide transition to this direction formed divided labor market, and this structural feature of the labor market can bee seen even in micro data.

\section{References}

Abe, Yukiko, "A comparison of wage structures in the United States and Japan: Results from cell mean regressions," The Japanese Economic Review, June 2000, 51 (2), 252-267.

Alexander, Arthur J., "Income, experience, and the structure of internal labor markets," The Quarterly Journal of Economics, February 1974, 88 (1), 63-85.

Altonji, Joseph G. and Charles R. Pierret, "Learning and statistical discrimination," The Quarterly Journal of Economics, February 2001, 116 (1), 313-350.

Aoki, Masahiko, Information, incentives, and bargaining in the Japanese economy, Cambridge: Cambridge University Press, 1988.

Arrow, Kenneth, "Higher education as a filter," Journal of Public Economics, July 1973, 2 (3), 193-216.

Autor, David H., Lawrence F. Katz, and Melissa S. Kearney, "The polarization of the U.S. labor market," The American Economic Review, May 2006, 96 (2), 189-194.

Baker, George and Bengt Holmstrom, "Internal labor markets: Too many theories, too few facts," The American Economic Review, May 1995, 85 (2), 255-259.

, Michael Gibbs, and Bengt Holmstrom, "The internal economics of the firm: Evidence from personnel data," The Quarterly Journal of Economics, November 1994a, 109 (4), 881-919.

and __ , "The wage policy of a firm," The Quarterly Journal of Economics, November 1994b, 109 (4), 921-955.

Bauer, Thomas K. and John P. Haisken-DeNew, "Employer learning and the returns to schooling," Labour Economics, May 2001, 8 (2), 161-180.

Bauer, Thomas, Patrick J. Dross, and John P. Haisken-DeNew, "Sheepskin effects in Japan,” International Journal of Manpower, 2005, 26 (4), 320-379.

Beaudry, Paul and John DiNardo, "The effect of implicit contracts on the movement of wages over the business cycle: Evidence from micro data," The Journal of Political Economy, August 1991, 99 (4), 665-688.

Bedard, Kelly, "Human capital versus signaling models: University access and high school dropouts," The Journal of Political Economy, August 2001, 109 (4), 749-775. 
Belman, Dale and John S. Heywood, "Sheepskin effects in the returns to education: An examination of women and minorities," The Review of Economics and Statistics, November 1991, 73 (4), 720-724.

and __ , "Sheepskin effects by cohort: Implications of job matching in a signalling model," Oxford Economic Papers, October 1997, 49 (4), 623-637.

Bitzan, John D., "Do sheepskin effects help explain racial earning differences?," Economics of Education Review, December 2009, 28 (6), 759-766.

Bollinger, Christopher and Barry T. Hirsch, "Match bias from earnings imputation in the Current Population Survey: The case of imperfect matching," Journal of Labor Economics, December 2006, 24 (3), 483-519.

Broadberry, S. N., “Technological leadership and productivity leadership in manufacturing since the industrial revolution: Implications for the convergence debate," The Economic Journal, March 1994, 104 (423), 291-302.

Burdett, Ken and Eric Smith, "The low skill trap," European Economic Review, September 2002, 46 (8), 1439-1451.

Caponi, Vincenz and Miana Plesca, "Post-secondary education in Canada: Can ability bias explain the earnings gap between college and university graduates?," Canadian Journal of Economics, July 2009, 42 (3), 1100-1131.

Card, David and Alan B. Krueger, "Does school quality matter?: Returns to education and the characterization of public schools in the United States," The Journal of Political Economy, February 1992, 100 (1), 1-40.

Chevalier, Arnaud, Colm Harmon, Ian Walker, and Yu Zhu, "Does education raise productivity, or just reflect it?," The Economic Journal, November 2004, 114 (499), F499F517.

Chuma, Hiroyuki, “Is Japan's long-term employment system changing?," in Isao Ohashi and Toshiaki Tachibanaki, eds., Internal labour markets, incentives and employment, Macmillan Press London 1998, pp. 225-268.

Clark, Melissa A. and David A. Jaeger, "Natives, the foreign-born and high school equivalents: New evidence on the returns to the GED," Journal of Population Economics, October 2006, 19 (4), 769-793.

Doeringer, Peter B. and Michael J. Piore, Internal labor markets and manpower analysis, Lexington, MA: Heath Lexington Books, 1971.

Dohmen, Thomas J., "Performance, seniority, and wages: Formal salary systems and individual earnings profiles," Labour Economics, December 2004, 11 (6), 741-763. 
Fallon, P. R. and P. R. G. Layard, "Capital-skill complementarity, income distribution, and output accounting," The Journal of Political Economy, April 1975, 83 (2), 279-302.

Farber, Henry S. and Robert Gibbons, "Learning and wage dynamics," The Quarterly Journal of Economics, November 1996, 111 (4), 1007-1047.

Ferrer, Ana M. and W. Craig Riddell, "The role credentials in the Canadian labour market," Canadian Journal of Economics, November 2002, 35 (4), 879-905.

and __ , "Education, credentials, and immigrant earnings," Canadian Journal of Economics, February 2008, 41 (1), 186-216.

Galindo-Rueda, Fernando, "Employer learning and schooling-related statistical discrimination in Britain," May 2003. Institute for the Study of Labor, Germany, IZA Discussion Paper series, No. 778.

Gathmann, Christina and Uta Schoenberg, "How general is human capital?: A task-based approach," Journal of Labor Economics, January 2010, 28 (1), 1-49.

Gibbons, Robert and Michael Waldman, "A theory of wage and promotion dynamics inside firms," The Quarterly Journal of Economics, November 1999, 114 (4), 1321-1358.

, Lawrence F. Katz, Thomas Lemieux, and Daniel Parent, "Comparative advantage, learning, and sectoral wage determination," Journal of Labor Economics, October 2005, $23(4), 681-724$.

Godo, Yoshihisa and Yujiro Hayami, "Catching up in education in the economic catch-up of Japan with the United States," Economic Development and Cultural Change, July 2002, 50 (4), 961-978.

Goldin, Claudia, "America's graduation from high school: The evolution and spread of secondary schooling in the twentieth century," The Journal of Economic History, June 1998, 58 (2), 345-374.

, "Egalitarianism and the returns to education during the Great Transformation of American education," The Journal of Political Economy, December 1999, 107 (s6), S65-S94.

, "The human-capital century and American leadership: Virtues of the past," The Journal of Economic History, June 2001, 61 (2), 263-292.

and Lawrence F. Katz, "Technology, skill and the wage structure: Insights from the past," The American Economic Review, May 1996, 86 (2), 252-257.

and __ , "The origins of technology-skill complementarity," The Quarterly Journal of Economics, August 1998, 113 (3), 693-732.

and Robert A. Margo, "The Great Compression: The wage structure in the United States at mid-century," The Quarterly Journal of Economics, February 1992, 107 (1), $1-34$. 
Gordon, Andrew, The evolution of labor relations in Japan: Heavy industry, 1853-1955, Cambridge, MA: Council on East Asian Studies, Harvard University, 1985.

Gordon, Robert J., "Why U.S. wage and employment behavior differs from that in Britain and Japan," The Economic Journal, March 1982, 92 (365), 13-44.

Groot, Wim and Hessel Oosterbeek, "Earning effects of different components of schooling: Human capital versus screening," The Review of Economics and Statistics, May 1994, 76 (2), 317-321.

Hall, Robert E., "Employment fluctuations and wage rigidity," The Brookings Papers on Economic Activity, September 1980, (2), 91-124.

, "The importance of lifetime jobs in the US economy," The American Economic Review, September 1982, 72 (4), 716-724.

Hansen, W. Lee, Burton A. Weisbrod, and William T. Scanlon, "Schooling and earnings of low achievers," The American Economic Review, June 1970, 60 (3), 409-418.

Hashimoto, Masanori and John Raisian, "Employment tenure and earnings profiles in Japan and the United States," The American Economic Review, September 1985, 75 (4), 721735 .

Hersch, Joni, "Profiling the new immigrant worker: The effects of skin color and height," Journal of Labor Economics, April 2008, 26 (2), 345-386.

Heywood, John S., "How widespread are sheepskin returns to education in the U.S.?," Economics of Education Review, September 1994, 13 (3), 227-234.

Higuchi, Yoshio, "Effects of job training and productivity growth on retention of male and female workers in Japan," in Toshiaki Tachibanaki, ed., Labour market and economic performance: Europe, Japan and the USA, St. Martin's Press New York 1994, pp. 155182.

Hungerford, Thomas and Gary Solon, "Sheepskin effects in the returns to education," The Review of Economics and Statistics, February 1987, 69 (1), 175-177.

Ishikawa, Tsuneo, Income and wealth, Oxford: Oxford University Press, 2001.

Jaeger, David A. and Marianne E. Page, "Degrees matter: New evidence on sheepskin effects in the returns to education," The Review of Economics and Statistics, November 1996, 78 (4), 733-740.

Jensen, Robert, "The (perceived) returns to education and the demand for schooling," The Quarterly Journal of Economics, 2010, 125 (2).

Katz, Lawrence F. and Ana L. Revenga, "Changes in the structure of wages: The United States vs Japan," Journal of the Japanese and International Economies, December 1989, 3 (4), 522-553. 
kevin J. Denny and Colm P. Harmon, "Testing for sheepskin effects in earnings equations: Evidence for five countries," Applied Economics Letters, Sep 2001, 8 (9), 635-637.

Kiley, Michael T, "The supply of skilled labour and skill-biased technological progress," The Economic Journal, October 1999, 109 (458), 708-724.

Kuhn, Peter and Catherine Weinberger, "Leadership skills and wages," Journal of Labor Economics, July 2005, 23 (3), 395-436.

Lang, Kevin and David Kropp, "Human capital versus sorting: The effects of compulsory attendance laws," The Quarterly Journal of Economics, August 1987, 101 (3), 609-624.

Lange, Fabian, “The speed of employer learning," Journal of Labor Economics, January 2007, 25 (1), 1-35.

Layard, Richard and George Psacharopoulos, "The screening hypothesis and the return to education," The Journal of Political Economy, September-October 1974, 82 (5), 985998.

Lluis, Stéphanie, "The role of comparative advantage and learning in wage dynamics and intrafirm mobility: Evidence from Germany," Journal of Labor Economics, October 2005, $23(4), 725-767$.

MacGuinnes, S., "Graduate overeducation as a sheepskin effect: Evidence from Northern Ireland," Applied Economics, March 2003, 35 (5), 597-608.

Marglin, Stephen, "What do bosses do?: The origins and functions of hierarchy in capitalist production," The Review of Radical Political Economics, Summer 1974, 6 (2), 60-112.

McDonald, James Ted and Christpher Worswick, "Wages, implicit contracts, and the business cycle: Evidence from Canadian micro data," The Journal of Political Economy, August 1999, 107 (4), 884-892.

Milgrom, Paul and John Roberts, Economics, organization, and management, Englewood Cliffs, NJ: Prentice Hall, 1992.

Mincer, Jacob and Yoshio Higuchi, "Wage structure and labor turnover in the United States and Japan," Journal of the Japanese and International Economies, June 1988, 2 (2), 97-133.

Moriguchi, Chiaki, "Implicit contracts, the Great Depression, and institutional change: a comparative analysis of U.S. and Japanese employment relations, 1920-1940," The Journal of Economic History, September 2003, 63 (3), 625-665.

Münich, Daniel, Jan Svejnar, and Katherine Terrell, "Returns to human capital under communist wage grid and during the transition to a market economy," The Review of Economics and Statistics, February 2005a, 87 (1), 100-123. 
_ _ _ a , and _ _ _Is women's human capital valued more by markets than by planners?," Journal of Comparative Economics, June 2005b, 33 (2), 278-299.

Nakamura, Naofumi, “Sengo Kamaishi seitetsujo ni okeru jukuren no saihen: hozen shokuba no jirei (From apprenticeships to firm-specific skills: a case of the maintenance workshop in the post-war Kamaishi Steel Works)," Shakai Kagaku Kenkyu (The Journal of Social Science), March 2010, 61 (5-6), 3-26. Institute of Social Science, The University of Tokyo.

Novack, David E. and Richard Perlman, "The structure of wages in the American iron and steel industry, 1860-1890," The Journal of Economic History, September 1962, 22 (3), 334-347.

Odaka, Konosuke, "The dual strucutre of the Japanese economy," in Takafusa Nakamura and Konosuke Odaka, eds., The economic history of Japan: 1600-1990, volume 3: Economic history of Japan 1914-1955: A dual strucutre, Oxford University Press New York 2003, pp. 111-136.

Ohkusa, Yasushi and Souichi Ohta, "An empricial study of the wage-tenure profile in Japanese manufacturing," Journal of the Japanese and International Economies, June 1994, 8 (2), 173-203.

Oleopoulos, Philip, "Estimating average and local average treatment effects of education when compulsory schooling laws really matter," The American Economic Review, March 2005, 96 (1), 152-175.

Ono, Hiroshi, "Lifetime employment in Japan: Concepts and measurements," Journal of the Japanese and International Economies, March 2010, 24 (1), 1-27.

Oyer, Paul, "Ability and employer learning: Evidence from the economist labor market," Journal of the Japanese and International Economies, June 2008, 22 (2), 268-289.

Parent, Daniel, "Wages and mobility: The impact of employer-provided training," Journal of Labor Economics, April 1999, 17 (2), 298-317.

, "Industry-specific capital and the wage profile: Evidence from the National Longitudinal Survey of Youth and the Panel Study of Income Dynamics," Journal of Labor Economics, April 2000, 18 (2), 306-323.

Park, Heum Jin, "Estimation of sheepskin effects using the old and the new measures of educational attainment in the Current Population Survey," Economics Letters, February 1999, 62 (2), 237-240.

Patrinos, Harry Anthony, "Non-linearities in the returns to education: Sheepskin effects or threshold levels of human capital?," Applied Economics Letters, March 1996, 3 (3), 171-173. 
Pinkston, Joshua C., "Screening discrimination and the determinants of wages," Labour Economics, December 2003, 10 (6), 643-658.

, "A model of asymmetric employer learning with testable implications," The Review of Economic Studies, 2009, 76 (1), 367-394.

Poletaev, Maxim and Chris Robinson, "Human capital specificity: Evidence from the Dictionary of Occupational Titles and displaced worker survey, 1984-2000," Journal of Labor Economics, July 2008, 26 (3), 387-420.

Pons, Empar, "Diploma effects by gender in the Spanish labour market," Labour, March 2006, 20 (1), 139-157.

and Juan M. Blanco, "Sheepskin effects in the Spanish labour market: A public-sector analysis," Education Economics, September 2005, 13 (3), 331-347.

Riley, John G., "Testing the educational screening hypothesis," The Journal of Political Economy, October 1979, 87 (5-2), s227-s252.

Schönberg, Uta, “Testing for asymmetric employer learning," Journal of Labor Economics, October 2007, 25 (4).

Shaw, Kathryn and Edward P. Lazer, "Tenure and output," Labour Economics, August 2008, 15 (4), 705-724.

Silles, Mary, "Sheepskin effects in the returns to education," Applied Economics Letters, February 2008, 15 (3), 217-219.

Spence, Michael, “Job market signaling,” The Quarterly Journal of Economics, August 1973, 87 (3), 355-374.

, "Signaling in retrospect and the informational structure of markets," The American Economic Review, June 2002, 92 (3), 434-459.

Stigler, George J., "Information in the labor market," The Journal of Political Economy, October 1962, 70 (5-2), 94-105.

Stiglitz, Joseph E., "The theory of "screening," education, and the distribution of income," The American Economic Review, June 1975, 65 (3), 283-300.

Stone, Kathrine, "The origins of job structures in the steel industry," The Review of Radical Political Economics, Summer 1974, 6 (2), 113-173.

Sugayama, Shinji, "Shusha” shakai no tanjo: Blue collar kara white collar he (Birth of the corporate society: from blue collar to white collar), Nagoya: Nagoya University Press, 2011.

Tabman, Paul J. and Terence J. Wales, "Higher education, mental ability, and screening," The Journal of Political Economy, January 1973, 81 (1), 28-55. 
Trostel, Philip and Ian Walker, "Sheepskin effects in work behaviour," Applied Economics, January 2004, 36 (17), 1959-1966.

Tyler, John H., Richard J. Murnane, and John B. Willett, "Estimating the labor market signaling value of GED," The Quarterly Journal of Economics, May 2000, 115 (2), 431468.

Ueshima, Yasuhiro, "Why wages equalized in the high-speed growth era: Japanese manufacturing, 1961-1969," Journal of the Japanese and International Economies, March 2003, $17(1), 33-54$.

, Takuji Funaba, and Takenori Inoki, "New technology and demand for educated workers: The experience of Japanese manufacturing in the ear of high-speed growth," Journal of the Japanese and International Economies, March 2006, 20 (1), 50-76.

Ujihara, Shojiro, Nihon rodo mondai kenkyu (Research on industrial relations in Japan), Tokyo: The University of Tokyo Press, 1966.

Umezaki, Osamu, "Keiei gorika to tokai tenshutsu: 1960 nendai ni okeru naibu rodo shijo keisei no ichi sokumen (Restructuring of Kamaishi Iron and Steel Works and the transfer of emoloyees to Tokai Iron and Steel Works: an analysis of the internal labour market formation in the 1960s)," Shakai Kagaku Kenkyu (The Journal of Social Science), March 2010, 61 (5-6), 27-54. Institute of Social Science, The University of Tokyo.

Weinberg, Bruce A., "Long-term wage fluctuations with industry-specific human capital," Journal of Labor Economics, January 2001, 19 (1), 231-264.

Williamson, Oliver, The economic institutions of capitalism: Firms, markets, relational contracting, New York: The Free Press, 1985.

, Michael Wachter, and Jeffrey Harris, "Understanding the employment relation: the analysis of idiosyncratic exchange," The Bell Journal of Economics, Spring 1975, 6 (1), 250-278.

Wolpin, Kenneth I., "Education and screening," The American Economic Review, December 1977, 67 (5), 949-958. 
Table 1 Emplyee numbers, years of schooling, and previous experience across cohorts.

\begin{tabular}{|c|c|c|c|c|c|c|c|c|c|c|}
\hline \multirow{2}{*}{$\begin{array}{l}\text { Year } \\
\text { joined } \\
\text { yj1928 }\end{array}$} & \multirow{2}{*}{$\begin{array}{l}\begin{array}{c}\text { Number } \\
\text { of } \\
\text { employees } \\
\text { who joined }\end{array} \\
1\end{array}$} & \multirow{2}{*}{$\begin{array}{r}\begin{array}{c}\text { Number } \\
\text { of } \\
\text { observations }\end{array} \\
24\end{array}$} & \multicolumn{4}{|c|}{$\begin{array}{l}\text { Years of schooling } \\
\text { (yos) }\end{array}$} & \multicolumn{4}{|c|}{$\begin{array}{c}\text { Years of previous experience } \\
(\mathrm{pvr})\end{array}$} \\
\hline & & & 9 & 9 & 9 & 9.00 & 3 & 3 & 3 & 3.00 \\
\hline yj1929 & 1 & 38 & 8 & 8 & 8 & 8.00 & 1 & 1 & 1 & 1.00 \\
\hline yj1930 & 1 & 28 & 8 & 8 & 8 & 8.00 & 2 & 2 & 2 & 2.00 \\
\hline yj1931 & 0 & 0 & n.a. & n.a. & n.a. & n.a. & n.a. & n.a. & n.a. & n.a. \\
\hline yj1932 & 0 & 0 & n.a. & n.a. & n.a. & n.a. & n.a. & n.a. & n.a. & n.a. \\
\hline yj1933 & 3 & 81 & 8 & 8 & 8 & 8.00 & 5 & 2 & 2 & 2.85 \\
\hline yj1934 & 2 & 56 & 8 & 6 & 6 & 6.82 & 11 & 5 & 5 & 7.46 \\
\hline yj1935 & 5 & 141 & 8 & 8 & 8 & 8.00 & 9 & 1 & 1 & 3.96 \\
\hline yj1936 & 7 & 152 & 8 & 8 & 8 & 8.00 & 9 & 1 & 6 & 6.36 \\
\hline yj1937 & 7 & 193 & 8 & 6 & 8 & 7.75 & 12 & 1 & 8 & 6.55 \\
\hline yj1938 & 18 & 495 & 8 & 6 & 8 & 7.51 & 13 & 0 & 6 & 5.44 \\
\hline yj1939 & 39 & 1,010 & 9 & 6 & 8 & 7.91 & 13 & 0 & 5 & 5.21 \\
\hline yj1940 & 41 & 1,053 & 8 & 6 & 8 & 7.81 & 12 & 0 & 6 & 5.54 \\
\hline yj1941 & 44 & 998 & 9 & 6 & 8 & 7.85 & 13 & 0 & 4 & 4.80 \\
\hline yj1942 & 29 & 651 & 9 & 6 & 8 & 7.62 & 16 & 0 & 3 & 4.57 \\
\hline yj1943 & 23 & 522 & 9 & 6 & 8 & 7.98 & 14 & 0 & 2 & 3.87 \\
\hline yj1944 & 26 & 564 & 8 & 6 & 8 & 7.60 & 16 & 0 & 2 & 4.47 \\
\hline yj1945 & 17 & 376 & 8 & 6 & 8 & 7.77 & 3 & 0 & 1 & 0.89 \\
\hline yj1946 & 17 & 344 & 8 & 6 & 8 & 7.75 & 22 & 0 & 1 & 3.70 \\
\hline yj1947 & 11 & 203 & 8 & 6 & 8 & 7.82 & 3 & 0 & 1 & 0.98 \\
\hline yj1948 & 283 & 5,298 & 16 & 6 & 8 & 8.13 & 23 & 0 & 9 & 9.48 \\
\hline yj1949 & 259 & 4,532 & 15 & 6 & 8 & 8.09 & 21 & 0 & 8 & 8.55 \\
\hline yj1950 & 37 & 609 & 12 & 6 & 9 & 8.39 & 26 & 0 & 2 & 5.74 \\
\hline yj1951 & 53 & 857 & 15 & 6 & 8 & 7.76 & 21 & 2 & 9 & 9.36 \\
\hline yj1952 & 7 & 104 & 9 & 6 & 8 & 7.82 & 10 & 5 & 7 & 7.33 \\
\hline yj1953 & 13 & 154 & 12 & 9 & 9 & 9.16 & 4 & 0 & 3 & 2.77 \\
\hline yj1954 & 19 & 220 & 12 & 9 & 9 & 9.82 & 3 & 0 & 3 & 2.30 \\
\hline yj1955 & 11 & 122 & 9 & 9 & 9 & 9.00 & 3 & 2 & 3 & 2.88 \\
\hline yj1956 & 91 & 910 & 15 & 6 & 9 & 8.93 & 20 & 0 & 7 & 7.33 \\
\hline yj1957 & 69 & 620 & 15 & 6 & 9 & 9.08 & 18 & 0 & 6 & 6.75 \\
\hline yj1958 & 25 & 189 & 9 & 9 & 9 & 9.00 & 9 & 2 & 3 & 3.10 \\
\hline yj1959 & 87 & 586 & 12 & 8 & 9 & 10.05 & 15 & 0 & 3 & 3.83 \\
\hline yj1960 & 47 & 250 & 12 & 9 & 9 & 10.11 & 28 & 0 & 3 & 4.84 \\
\hline yj1961 & 35 & 148 & 12 & 9 & 9 & 9.16 & 12 & 1 & 3 & 3.82 \\
\hline yj1962 & 84 & 279 & 12 & 8 & 12 & 10.70 & 9 & 0 & 2 & 1.92 \\
\hline yj1963 & 41 & 71 & 15 & 6 & 8 & 8.70 & 35 & 2 & 20 & 19.51 \\
\hline yj1964 & 15 & 71 & 15 & 6 & 8 & 8.70 & 35 & 2 & 20 & 19.51 \\
\hline yj1965 & 9 & 29 & 12 & 8 & 12 & 10.72 & 5 & 1 & 1 & 2.28 \\
\hline yj1966 & 10 & 20 & 12 & 12 & 12 & 12.00 & 2 & 0 & 1 & 0.95 \\
\hline yj1967 & 8 & 15 & 12 & 9 & 9 & 10.20 & 14 & 1 & 5 & 7.40 \\
\hline total & 1,495 & 22,013 & & & & & & & & \\
\hline
\end{tabular}

Notes : Previous experience: Years after graduating school, before employed by the firm. 
Table 2 Cohort effect in panel estimations.

\begin{tabular}{|c|c|c|c|c|c|c|}
\hline & $2-1$ & & & $2-2$ & & \\
\hline Estimation method & panel least squa & ares & & & & \\
\hline Dependent variable & $\log (\mathrm{rw})$ & & & & & \\
\hline Cross-section & pooled (no cross & s-section d & dummy) & & & \\
\hline Period (year) & fixed (year dum & nmies inser & rted) & & & \\
\hline Indepedent variables & coefficient $t$ & $t$ statistic & probability & coefficient & $t$ statistic & probability \\
\hline $\mathrm{c}$ & -0.3643 & -18.0062 & 0.0000 & -0.2349 & -9.7127 & 0.0000 \\
\hline $\log (\mathrm{yos})$ & 0.1785 & 26.2363 & 0.0000 & 0.1828 & 27.1514 & 0.0000 \\
\hline $\log ($ epr $)$ & 0.2175 & 85.1986 & 0.0000 & 0.2444 & 84.4775 & 0.0000 \\
\hline $\log ($ ten $)$ & 0.0356 & 13.1963 & 0.0000 & & & \\
\hline yj1928-1929 & 0.6802 & 30.3373 & 0.0000 & -0.1048 & -1.4048 & 0.1601 \\
\hline уj1930-1931 & 0.6972 & 25.1817 & 0.0000 & -0.0351 & -0.4159 & 0.6775 \\
\hline yj1932-1933 & 0.6147 & 30.7214 & 0.0000 & -0.0795 & -1.2426 & 0.2140 \\
\hline уj1934-1935 & 0.6670 & 39.1088 & 0.0000 & -0.0924 & -1.6770 & 0.0936 \\
\hline уj1936-1937 & 0.6295 & 40.1487 & 0.0000 & -0.0815 & -1.6164 & 0.1060 \\
\hline yj1938-1939 & 0.6341 & 44.3434 & 0.0000 & -0.0899 & -1.9786 & 0.0479 \\
\hline уj1940-1941 & 0.5896 & 42.3080 & 0.0000 & -0.0898 & -2.1161 & 0.0343 \\
\hline yj1942-1943 & 0.5479 & 39.5355 & 0.0000 & -0.0658 & -1.6606 & 0.0968 \\
\hline yj1944-1945 & 0.4828 & 35.2916 & 0.0000 & -0.0991 & -2.6911 & 0.0071 \\
\hline уj1946-1947 & 0.4485 & 32.4434 & 0.0000 & -0.1235 & -3.5827 & 0.0003 \\
\hline yj1948-1949 & 0.4336 & 34.2090 & 0.0000 & -0.0557 & -1.8772 & 0.0605 \\
\hline yj1950-1951 & 0.3628 & 28.6223 & 0.0000 & -0.0817 & -2.9965 & 0.0027 \\
\hline уj1952-1953 & 0.3265 & 23.1302 & 0.0000 & -0.0431 & -1.5500 & 0.1212 \\
\hline yj1954-1955 & 0.3004 & 22.3837 & 0.0000 & -0.0033 & -0.1311 & 0.8957 \\
\hline уj1956-1957 & 0.1744 & 14.5807 & 0.0000 & -0.1139 & -5.9023 & 0.0000 \\
\hline yj1958-1959 & 0.1253 & 10.3818 & 0.0000 & -0.0738 & -4.1333 & 0.0000 \\
\hline yj1960-1961 & 0.0865 & 6.8358 & 0.0000 & -0.0634 & -3.4739 & 0.0005 \\
\hline yj1962-1963 & 0.1120 & 9.0093 & 0.0000 & 0.0287 & 1.5465 & 0.1220 \\
\hline yj1964-1965 & 0.0081 & 0.5814 & 0.5610 & -0.0077 & -0.2447 & 0.8067 \\
\hline y.j1966-1967 & 0.1772 & 7.5325 & 0.0000 & 0.2381 & 3.6260 & 0.0003 \\
\hline yj1928-1929× $\log ($ ten $)$ & & & & 0.0214 & 8.8438 & 0.0000 \\
\hline yj1930-1931×log(ten) & & & & 0.0198 & 6.2121 & 0.0000 \\
\hline yj1932-1933× $\log ($ ten $)$ & & & & 0.0218 & 9.7056 & 0.0000 \\
\hline yj1934-1935× $\log ($ ten $)$ & & & & 0.0269 & 13.8477 & 0.0000 \\
\hline yj1936-1937× $\log ($ ten $)$ & & & & 0.0267 & 14.7740 & 0.0000 \\
\hline yj1938-1939× $\log ($ ten $)$ & & & & 0.0306 & 18.0433 & 0.0000 \\
\hline yj1940-1941×log(ten) & & & & 0.0309 & 18.2999 & 0.0000 \\
\hline yj1942-1943× $\log ($ ten $)$ & & & & 0.0301 & 17.4422 & 0.0000 \\
\hline yj1944-1945×log(ten) & & & & 0.0318 & 18.0134 & 0.0000 \\
\hline yj1946-1947× $\log ($ ten $)$ & & & & 0.0360 & 19.1470 & 0.0000 \\
\hline yj1948-1949× $\log ($ ten $)$ & & & & 0.0338 & 20.2743 & 0.0000 \\
\hline yj1950-1951×log(ten) & & & & 0.0357 & 19.9709 & 0.0000 \\
\hline yj $1952-1953 \times \log ($ ten $)$ & & & & 0.0342 & 13.8339 & 0.0000 \\
\hline yj1954-1955× $\log ($ ten $)$ & & & & 0.0322 & 13.3066 & 0.0000 \\
\hline yj1956-1957× $\log ($ ten $)$ & & & & 0.0398 & 20.4086 & 0.0000 \\
\hline yj1958-1959× $\log ($ ten $)$ & & & & 0.0363 & 14.3649 & 0.0000 \\
\hline yj1960-1961× $\log ($ ten $)$ & & & & 0.0349 & 9.4968 & 0.0000 \\
\hline yj1962-1963× $\log ($ ten $)$ & & & & 0.0242 & 4.4991 & 0.0000 \\
\hline yj1964-1965× $\log ($ ten $)$ & & & & 0.0322 & 3.2872 & 0.0010 \\
\hline yj1966-1967× $\log ($ ten $)$ & & & & 0.0197 & 0.6700 & 0.5029 \\
\hline year dummies & yes & & & yes & & \\
\hline cross-sections included & 1,490 & & & 1,490 & & \\
\hline periods included (years) & 41 (1929-1969) & & & $41(1929-1969)$ & & \\
\hline included observations & 22,045 & & & 22,045 & & \\
\hline adjusted $\mathrm{R}^{2}$ & 0.9622 & & & 0.9631 & & \\
\hline$F$ statistic & $8,911.6042$ & & 0.0000 & $7,016.7697$ & & 0.0000 \\
\hline
\end{tabular}




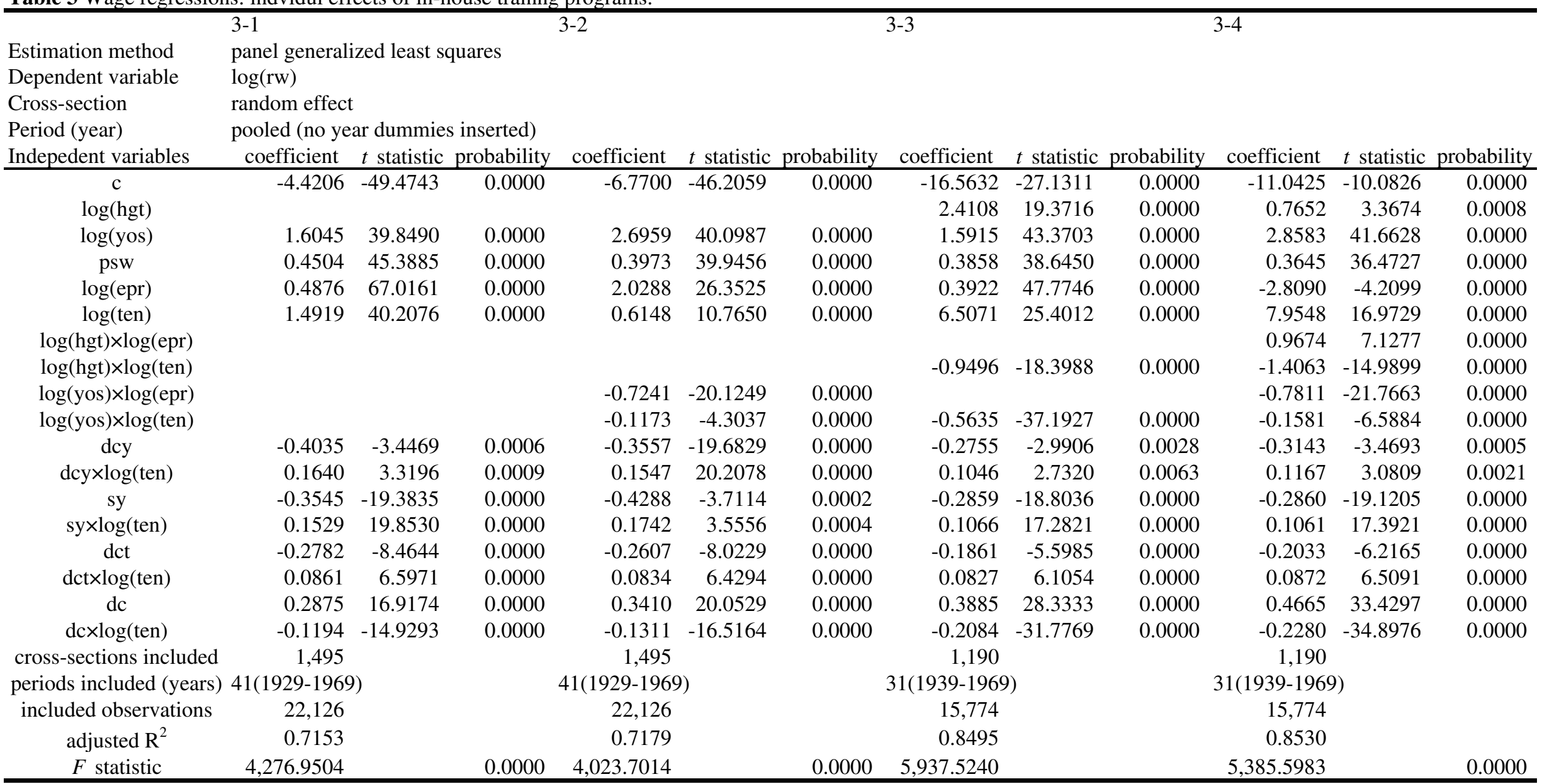


Table 4 Interaction of education and tenure/previous epxerience.

\begin{tabular}{|c|c|c|c|}
\hline \multirow[t]{2}{*}{$\begin{array}{l}\text { Estimation method } \\
\text { Dependent variable } \\
\text { Cross-section } \\
\text { Period (year) } \\
\text { Indepedent variables }\end{array}$} & $\begin{array}{l}\text { 4-1 } \\
\text { panel generali } \\
\log (\mathrm{rw}) \\
\text { random effect } \\
\text { pooled (no ye }\end{array}$ & ized least s & inserted) \\
\hline & coefficient & & \\
\hline $\mathrm{c}$ & 0.2786 & 7.5211 & 0.0000 \\
\hline $\log ($ yos $)$ & 0.4701 & 26.6533 & 0.0000 \\
\hline $\log (p v r)$ & -0.0552 & -7.0511 & 0.0000 \\
\hline $\log ($ ten $)$ & 0.3021 & 25.7110 & 0.0000 \\
\hline yj1928-1929×log(yos)×log(pvr) & -0.0762 & -2.1206 & 0.0340 \\
\hline yj1930-1931×log(yos)×log(pvr) & -0.0721 & -1.1802 & 0.2379 \\
\hline yj1932-1933× $\log ($ yos $) \times \log ($ pvr $)$ & -0.0547 & -2.3141 & 0.0207 \\
\hline yj1934-1935× $\log ($ yos $) \times \log ($ pvr $)$ & 0.0394 & 3.8687 & 0.0001 \\
\hline yj1936-1937× $\log ($ yos $) \times \log (\mathrm{pvr})$ & 0.0647 & 8.3687 & 0.0000 \\
\hline yj1938-1939× $\log ($ yos $) \times \log ($ pvr $)$ & 0.0679 & 12.9928 & 0.0000 \\
\hline yj1940-1941×log(yos)×log(pvr) & 0.0725 & 15.1548 & 0.0000 \\
\hline yj1942-1943× $\log ($ yos $) \times \log ($ pvr $)$ & 0.0878 & 17.3301 & 0.0000 \\
\hline yj1944-1945×log(yos)×log(pvr) & 0.0751 & 13.4498 & 0.0000 \\
\hline yj1946-1947× $\log ($ yos $) \times \log ($ pvr $)$ & 0.0698 & 10.9268 & 0.0000 \\
\hline yj1948-1949×log(yos)×log(pvr) & 0.1052 & 29.0775 & 0.0000 \\
\hline yj1950-1951×log $($ yos $) \times \log (\mathrm{pvr})$ & 0.0911 & 22.8328 & 0.0000 \\
\hline yj1952-1953×log(yos) $\times \log (\mathrm{pvr})$ & 0.1001 & 15.9854 & 0.0000 \\
\hline yj1954-1955× $\log ($ yos $) \times \log (\mathrm{pvr})$ & 0.0917 & 14.0185 & 0.0000 \\
\hline yj1956-1957×log(yos) $\times \log (\mathrm{pvr})$ & 0.0608 & 16.6241 & 0.0000 \\
\hline yj1958-1959× $\log ($ yos $) \times \log ($ pvr $)$ & 0.0392 & 9.5487 & 0.0000 \\
\hline yj1960-1961× $\log ($ yos $) \times \log ($ pvr $)$ & 0.0353 & 7.9487 & 0.0000 \\
\hline yj1962-1963× $\log ($ yos $) \times \log ($ pvr $)$ & 0.0168 & 3.1449 & 0.0017 \\
\hline yj1964-1965×log(yos)×log(pvr) & 0.0702 & 11.4393 & 0.0000 \\
\hline yj1966-1967×log(yos)×log(pvr) & 0.0443 & 5.0681 & 0.0000 \\
\hline yj1928-1929×log(yos)×log(ten) & 0.0441 & 3.3562 & 0.0008 \\
\hline yj1930-1931×log(yos)×log(ten) & 0.0421 & 1.9443 & 0.0519 \\
\hline yj1932-1933× $\log ($ yos $) \times \log ($ ten $)$ & 0.0366 & 3.3057 & 0.0009 \\
\hline yj1934-1935× $\log ($ yos $) \times \log ($ ten $)$ & 0.0087 & 1.1667 & 0.2433 \\
\hline yj1936-1937× $\log ($ yos $) \times \log ($ ten $)$ & -0.0118 & -1.7443 & 0.0811 \\
\hline yj1938-1939×log(yos)×log(ten) & -0.0095 & -1.6184 & 0.1056 \\
\hline yj1940-1941×log $($ yos $) \times \log ($ ten $)$ & -0.0193 & -3.3376 & 0.0008 \\
\hline yj1942-1943×log(yos)×log(ten) & -0.0316 & -5.4193 & 0.0000 \\
\hline yj1944-1945×log(yos)×log(ten) & -0.0318 & -5.4001 & 0.0000 \\
\hline yj1946-1947×log(yos)×log(ten) & -0.0343 & -5.6775 & 0.0000 \\
\hline yj1948-1949×log(yos)×log(ten) & -0.0732 & -13.2852 & 0.0000 \\
\hline yj1950-1951×log(yos) $\times \log ($ ten $)$ & -0.0726 & -12.7004 & 0.0000 \\
\hline yj1952-1953×log(yos) $\times \log ($ ten $)$ & -0.0931 & -13.9681 & 0.0000 \\
\hline yj1954-1955×log(yos) $\times \log ($ ten $)$ & -0.0943 & -15.2773 & 0.0000 \\
\hline yj1956-1957× $\log ($ yos $) \times \log ($ ten $)$ & -0.0914 & -16.3870 & 0.0000 \\
\hline yj1958-1959×log(yos) $\times \log ($ ten $)$ & -0.1022 & -17.7993 & 0.0000 \\
\hline yj1960-1961×log(yos)×log(ten) & -0.1132 & -17.7019 & 0.0000 \\
\hline yj1962-1963×log(yos) $\times \log ($ ten $)$ & -0.1106 & -16.0659 & 0.0000 \\
\hline yj1964-1965×log(yos) $\times \log ($ ten $)$ & -0.0777 & -8.1543 & 0.0000 \\
\hline yj1966-1967×log(yos) $\times \log ($ ten $)$ & -0.1435 & -9.5139 & 0.0000 \\
\hline dcy, sy, dct, dc & yes & & \\
\hline dcy $\times \log ($ ten $), \operatorname{sy} \times \log ($ ten $)$, dct $\times \log ($ ten $)$, dc $\times \log ($ ten $)$ & yes & & \\
\hline interaction of year dummy and yos: dyxyos & yes & & \\
\hline cross-sections included & 1,490 & & \\
\hline periods included (years) & 41(1929-1969 & & \\
\hline included observations & 22,045 & & \\
\hline adjusted $\mathrm{R}^{2}$ & 0.9652 & & \\
\hline$F$ statistic & $6,717.5996$ & & 0.0000 \\
\hline
\end{tabular}


Appendix List of variables.

\begin{tabular}{clr} 
variable & \multicolumn{1}{c}{ definition } & \\
rw & real daily wage. & \\
hgt & height when employed by the firm. & \\
yos & years of schooling. & \\
psw & postwar education generation (12 years old or younger in 1947). & dummy variable \\
epr & experience in the labor market: age-(5+yos)+1. & \\
pve & previous experience: age- $-(5+$ yos+ten)+1. Note: Every sample & \\
yj19XX & emolvee was hired bv the firm in the last vear of his record. & dummy variable \\
difXX-19YY of year joined: =1 if joined the firm in 19XX. & dummy of year joined: =1 ifjoined the firm from 19XX to 19YY. dummy variable \\
dy19XX & year dammy. & dummy variable \\
ten & tenure: (years after employed by the firm)+1. & \\
dcy & 1 if completed Development Center for Youth (from 1927 to 193: dummy variable \\
sy & 1 if completed School for Youth (from 1935 to 1948). & dummy variable \\
dct & 1 if completed Development Center for Technician (from 1939 to dummy variable \\
dc & 1 if completed Development Center (from 1946 to 1973). & dummy variable \\
\hline
\end{tabular}

